\title{
STRUCTURAL TRANSFORMATION,
} SERVICES DEEPENING, AND THE TRANSMISSIONOE MONETARY POLICY

Alessandro Galesi and Omar Rache di

Documentos de Trabajo.

N. 1615

\section{BANCODE ESPAÑA}

\author{
Eurosistema
}

2016

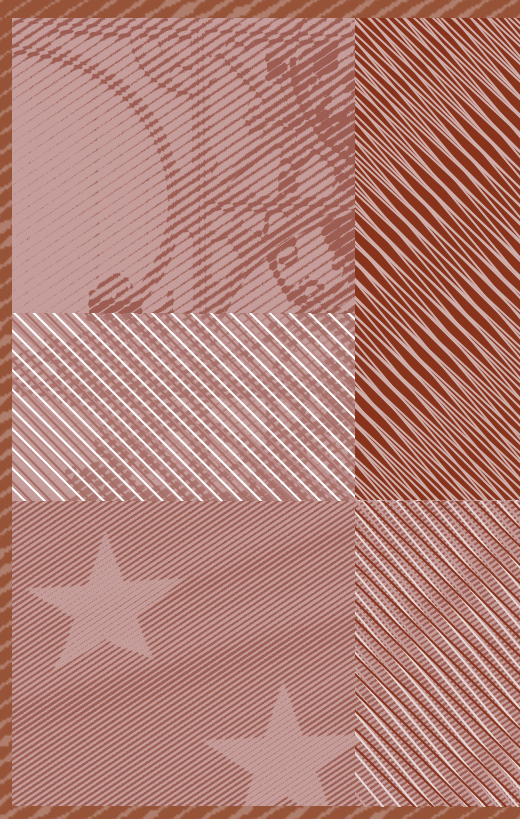


STRUCTURAL TRANSFORMATION, SERVICES DEEPENING,

AND THE TRANSMISSION OF MONETARY POLICY 
STRUCTURAL TRANSFORMATION, SERVICES DEEPENING, AND THE TRANSMISSION OF MONETARY POLICY ${ }^{(*)}$

Alessandro Galesi and Omar Rachedi ${ }^{(*)}$

BANCO DE ESPAÑA

$\left.{ }^{*}\right)$ The views expressed in this paper are those of the authors and do not necessarily represent the views of Banco de España or the Eurosystem. We thank Hafedh Bouakez, Francesco Furlanetto, Patrick Gruning, seminar participants at the Norges Bank and participants in the Workshop on Institutions, Individual Behavior and Economic Outcomes (Alghero) for useful comments and suggestions. The Supplementary Appendix to this paper is available on the web pages of the authors.

$\left.{ }^{\star \star}\right)$ alessandro.galesi@bde.es (Galesi), omar.rachedi@bde.es (Rachedi). 
The Working Paper Series seeks to disseminate original research in economics and finance. All papers have been anonymously refereed. By publishing these papers, the Banco de España aims to contribute to economic analysis and, in particular, to knowledge of the Spanish economy and its international environment.

The opinions and analyses in the Working Paper Series are the responsibility of the authors and, therefore, do not necessarily coincide with those of the Banco de España or the Eurosystem.

The Banco de España disseminates its main reports and most of its publications via the Internet at the following website: http://www.bde.es.

Reproduction for educational and non-commercial purposes is permitted provided that the source is acknowledged.

C BANCO DE ESPAÑA, Madrid, 2016

ISSN: 1579-8666 (on line) 


\section{Abstract}

Advanced economies are undergoing a structural transformation from manufacturing to services. We document that structural change comes with a process of services deepening: over time, both services and manufacturing become more intensive in service inputs. We argue that structural transformation and services deepening affect the transmission of monetary policy by increasing the relative importance of services, which have stickier prices than manufacturing. We study the implications of the U.S. sectoral reallocation with a New Keynesian model with two sectors connected by an input-output matrix, which varies endogenously over time. The rise of services dampens the responses of aggregate and sectoral inflation rates to a monetary policy shock. The changes in the responses of sectoral inflation rates are entirely driven by services deepening.

Keywords: New Keynesian model, intermediate inputs, input-output matrix.

JEL classification: E31, E43, E52, O41. 


\section{Resumen}

Las economías avanzadas están experimentando una transformación estructural de la industria hacia los servicios. Nosotros documentamos que el cambio estructural viene con un proceso de services deepening: a lo largo del tiempo, tanto los servicios como la industria utilizan más y más bienes intermedios del sector servicios. Nosotros argumentamos que la transformación estructural y el services deepening afectan a la transmisión de la política monetaria mediante el aumento de la importancia relativa de los servicios, que tienen precios más rígidos que la industria. En este documento, estudiamos las implicaciones de la reasignación sectorial de Estados Unidos. con un modelo neokeynesiano con dos sectores conectados por una matriz de entrada/salida, que varía con el tiempo de forma endógena. El aumento de los servicios disminuye las respuestas de las tasas de inflación agregadas y sectoriales a un choque de política monetaria. Los cambios en las respuestas de las tasas de inflación sectoriales están enteramente determinados por el services deepening.

Palabras clave: modelo neokeynesiano, bienes intermedios, matriz de entrada/salida.

Códigos JEL: E31, E43, E52, O41. 


\section{Introduction}

Over time advanced economies experience a process of structural transformation that shifts the economic activity from manufacturing to services. We document that structural transformation comes with a process of services deepening: both services and manufacturing are becoming more intensive in service inputs. In the U.S. in 1947 service inputs accounted for $62 \%$ of the total inputs used by the service sector, and $20 \%$ of the inputs used in manufacturing. In 2010 these shares have peaked up to $83 \%$ and $35 \%$, respectively.

We argue that the sectoral reallocation from manufacturing to services affects the transmission of monetary policy. Since services prices are much stickier than manufacturing prices ${ }^{1}$, the rise of services raises the sluggishness of inflation and dampens its response to monetary policy shocks.

We study the positive implications of structural transformation and services deepening using a New Keynesian model with two sectors, which are connected by an Input-Output matrix that changes endogenously over time. We calibrate the model to match the sectoral reallocation experienced by the U.S. from 1947 to 2005. The model predicts that over these six decades the contemporaneous response of aggregate inflation to monetary policy shocks decreases by $37 \%$. Also the responses of services inflation and manufacturing inflation drop by $7 \%$ and $10 \%$, respectively. The dampening of the reaction of inflation raises the real effects of monetary policy: the response of aggregate output to monetary policy shocks increases by $10 \%$.

We show that structural transformation and services deepening reduce the sensitivity of inflation to monetary policy shocks through different channels. Structural transformation works through a composition channel, that tilts the production towards services.

\footnotetext{
${ }^{1}$ There is ample evidence on services prices being stickier than manufacturing prices, e.g. Bils and Klenow (2004), Klenow and Kryvtsov (2008) and Nakamura and Steinsson (2008). The average duration of manufacturing prices is around 3 months, whereas the average duration of services prices ranges between 8 months and 13 months. Section 2.2 reviews the empirical evidence on price stickiness across sectors.
} 
Aggregate inflation becomes more sluggish although sectoral inflation rates barely change their dynamics. Instead, services deepening propagates through a marginal cost channel, that affects the behavior of each firm in either sector. As services and manufacturing increase the intensity of service inputs, marginal costs become stickier. Consequently, also sectoral prices become stickier and less responsive to monetary policy shocks.

Our theoretical framework is a standard Calvo staggered price New Keynesian model with two sectors - services and manufacturing - which are connected by an Input-Output matrix as in Bouakez et al. (2009): each sector produces output by using labor and a bundle of intermediate inputs of manufactured goods and services. The two sectors differ in the durability of the produced good and in the relative use of labor and intermediates. Importantly, the two sectors differ also in the degree of price stickiness.

To model the process of services deepening, we consider intermediates that are a CES aggregator of services inputs and manufacturing inputs. In the aggregator we also introduce a non-homothetic component that captures in a reduced form firms' in-house production of service inputs. $^{2}$ In the model, two forces drive the endogenous variation of the Input-Output matrix: $(i)$ a Baumol (1967) cost disease channel, which raises the share of service inputs when the relative productivity of manufacturing increases, as in Ngai and Pissarides (2007); (ii) the presence of the non-homothetic components in the intermediate aggregators, that raises the share of service inputs when output increases, even in the absence of movements in relative productivities.

In the quantitative analysis, we feed the model with the estimated series of sectoral productivities and calibrate it to match the changes in the service shares of intermediate inputs from 1947 to 2005. In this way, the model fully accounts for the services deepening experienced by the U.S. economy. Although the model is not calibrated to match the process of structural transformation, it succeeds in explaining around half of the rise in the service share of GDP. Then, we compare the model around the 1947 and 2005 steadystates. The two equilibria differ only in the levels of sectoral productivities. Throughout

\footnotetext{
${ }^{2}$ These components may be viewed as the firm-analogue of the level of subsistence introduced by Kongsamut et al. (2001) in the utility function of the household.
} 
our exercise, we keep fixed all the other parameters, included those of the Taylor rule. In this way, we can ask to what extent structural change and services deepening alone can alter the transmission of monetary policy shocks.

We find that moving from the 1947 steady-state to the 2005 one decreases the contemporaneous reaction of aggregate inflation to monetary policy shocks by $37 \%$. We decompose this result and find that services deepening accounts for one third of the change in aggregate inflation. Indeed, when we shut down the process of services deepening, by keeping fixed the Input-Output matrix, the reaction of aggregate inflation to monetary policy shocks shrinks by just $26 \%$.

We show that structural transformation reduces the sensitivity of inflation to monetary policy shocks mainly through a composition channel, that tilts the economic activities towards services. As services have stickier prices than manufacturing, the process of sectoral reallocation generates aggregate prices which adjust less frequently over time. Yet, the dynamics of each sectoral price barely change.

Instead, services deepening propagates through a different mechanism: a marginal cost channel that alters the dynamics of each sectoral price. As both sectors increase the use of service inputs, marginal costs become stickier and less responsive to shocks. The changes in the dynamics of marginal costs spill over to the behavior of sectoral prices. Indeed, with services deepening the responses of service inflation and manufacturing inflation to monetary policy shocks drop by $7 \%$ and $10 \%$.

The dampening in the response of inflation is accompanied by mildly stronger real effects of monetary policy shocks. The rise of services increases the contemporaneous reaction of aggregate output, services output and manufacturing output to monetary policy shocks by $10 \%, 3 \%$ and $8 \%$, respectively.

Overall we find that the process of sectoral reallocation alters the response of inflation to monetary policy shocks. This result adds to the literature that studies how the 
transmission of monetary policy has changed over time (e.g., Cogley and Sargent, 2001, 2005; Primiceri, 2005; Boivin and Giannoni, 2006; Pancrazi and Vukotic, 2016). For instance, Boivin and Giannoni (2006) and Pancrazi and Vukotic (2016) find a reduction in the response of inflation to monetary policy shocks from the 1980's on, and rationalize it through changes in either the stance of monetary policy or the volatility of shocks. We complement this strand of the literature by providing a novel channel that can generate low-frequency movements in the effectiveness of monetary policy. Since in our model both the Taylor rule and the volatility of shocks do not change over time, the variation in the transmission of monetary policy is entirely due to the processes of structural transformation and services deepening.

Our results provide a novel link between the sectoral composition of intermediates and the response of sectoral inflation to shocks. We test this implication by exploiting cross-country panel data. In particular, we focus on the response of manufacturing inflation to changes in manufacturing GDP. To identify causal effects, we instrument manufacturing GDP with a country-specific index of penetration of Chinese imports. This IV strategy follows the idea of Autor et al. (2013) that the emergence of China is a shock to manufacturing industries worldwide. Consistently with our theory, we find that manufacturing inflation responds less to (exogenous) changes in manufacturing value added in countries where manufacturing is more intensive in service inputs. In this way, we further validate our novel mechanism through which variations in the Input-Output matrix alter the dynamics of sectoral inflation rates.

This paper relates to the structural transformation literature, which documents that advanced economies are experiencing a rise of the service share in GDP, employment and consumption expenditures (e.g., Duarte and Restuccia, 2010; Herrendorf et al., 2013). We complement this evidence by showing that structural transformation comes with a services deepening. This process reminds the capital deepening emphasized by Acemoglu and Guerrieri (2008). Although capital deepening describes an increase in capital per capita, services deepening highlights the increase in the utilization of service inputs. 
This paper bridges the gap between the literatures on growth with sectoral reallocation and monetary policy with multi-sector models. ${ }^{3}$ As in Christiano et al. (2005), we study the reaction of output and inflation to a monetary policy shock. Following Carvalho (2006) and Bouakez et al. (2009), we highlight how the heterogeneity across sectors shapes the propagation of monetary policy shocks. We depart from this literature in two dimensions. First, we emphasize the importance of the sectoral composition of the intermediate inputs. Second, we show how variations in the sectoral shares affect the transmission of monetary policy.

Finally, this paper also links to the literature on the role of the inter-sectoral network as amplification mechanism of macroeconomic shocks, such as Long and Plosser (1983), Foerster et al. (2011) and Acemoglu et al. (2015). We contribute to this literature by documenting that the network structure across sectors is changing over time towards a higher use of service inputs. ${ }^{4}$

\section{Empirical Evidence}

\subsection{The Process of Services Deepening}

The structural transformation literature, such as Kongsamut et al. (2001), Duarte and Restuccia (2010), Buera and Kaboski (2012) and Herrendorf et al. (2013) among others, emphasizes that economies reallocate resources from manufacturing to services as they develop. This literature mainly focuses on the dynamics of value-added, employment

\footnotetext{
${ }^{3}$ For instance, Hulten (1978) emphasizes the role of intermediates on aggregate TFP growth. Huang and Liu (2005) and Bouakez et al. $(2009,2011)$ study the role of the Input-Output matrix on the transmission of monetary policy shocks. Moro (2012, 2015) and Carvalho and Gabaix (2013) discuss the role of structural transformation as a driver of macroeconomic fluctuations.

${ }^{4}$ Berlingieri (2014) shows the surge of the professional and business sector as provider of intermediate inputs, and studies the sectoral reallocation effects of exogenous changes in the Input-Output matrix. We show that services deepening does not only affect the U.S. economy, but it is a stylized fact that characterizes all world economies throughout their development. We also develop a model where services deepening is not assumed exogenous, but rather arises endogenously over time.
} 
and gross output. Figure 1 plots these shares computed for the U.S. economy from 1947 to 2010. Each share has been trending up since the late 1940's. The services value added share rises from a value of $69 \%$ in 1947 to $86 \%$ in 2010 . The services shares of employment and gross output display a similar behavior, by increasing from $59 \%$ and $53 \%$ in 1947 , up to $88 \%$ and $80 \%$ in 2010 , respectively.

Figure 1: U.S. Services Value Added, Employment and Gross Output Shares.

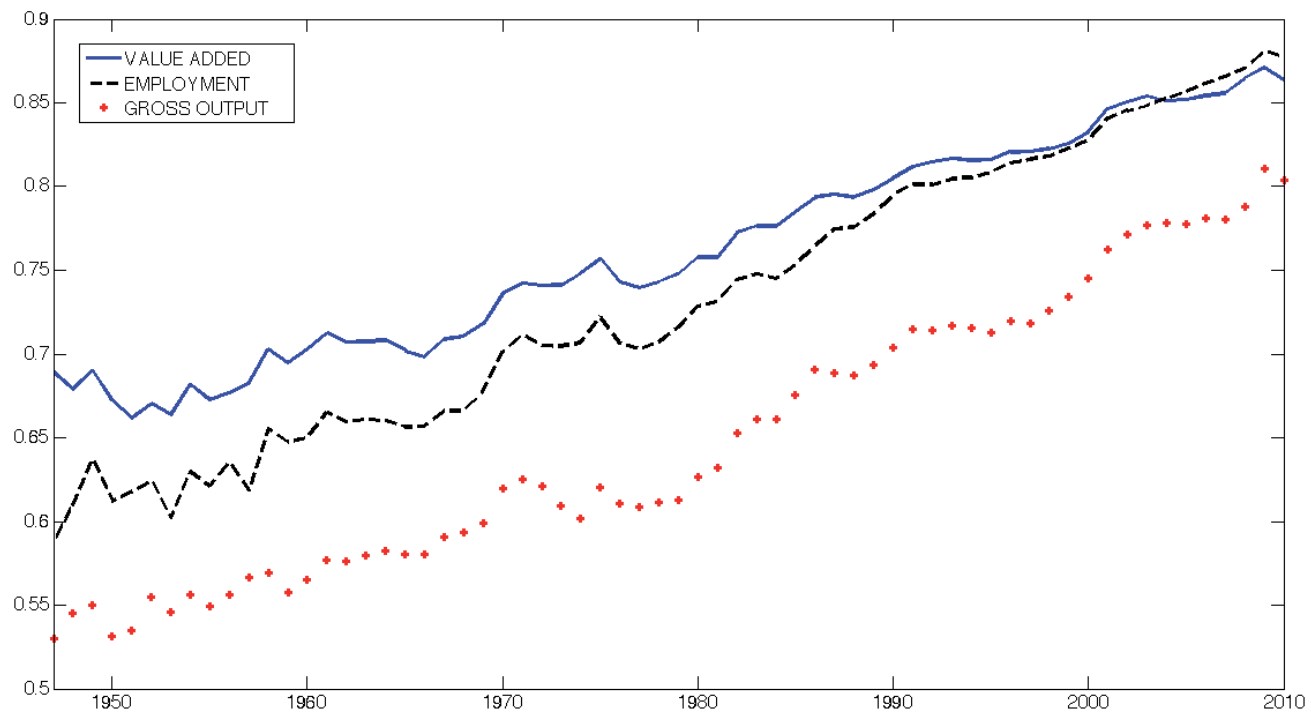

The figure shows the share of services in value added (continuous line), employment (dashed line) and gross output (crosses line) for the U.S. economy from 1947 to 2010. Data come from Jorgenson (2007) dataset.

We document a novel dimension of the process of sectoral reallocation that countries experience over their development. We show that over time both services and manufacturing become more intensive in service inputs. We refer to this new stylized fact as services deepening.

Figure 2 shows the dynamics of the share of service inputs in services and manufacturing for the U.S. economy over the last six decades. Both shares increase over time. The share of service inputs in services rises up to $83 \%$ in 2010 from a value of $62 \%$ in 1947. Similarly, the share of service inputs in manufacturing, which equals $20 \%$ in 1947 , increases up to $35 \%$ in 2010 . These dynamics are not unique to the U.S. economy. Using 
Figure 2: U.S. Services Intermediate Inputs in Services and Manufacturing.

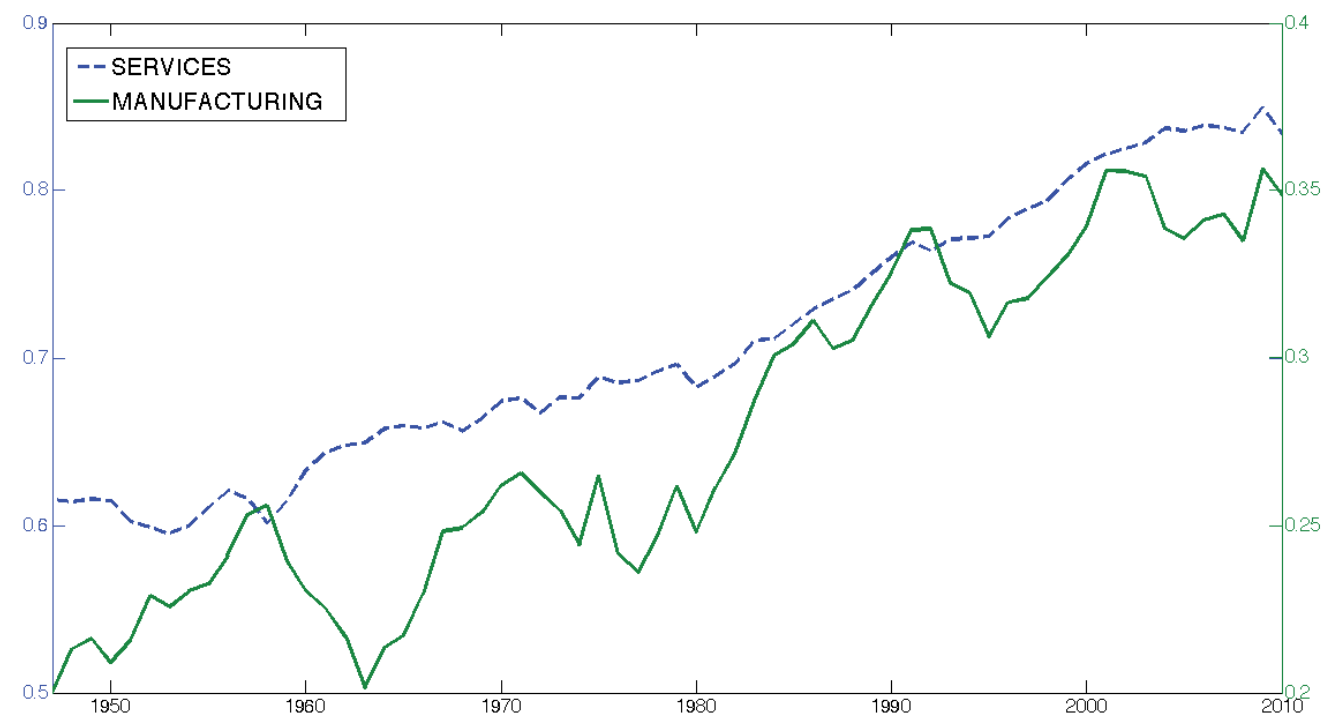

The figure shows the share of service intermediate inputs in the service sector (dashed line - left $\mathrm{y}$-axis) and the share of service intermediate inputs in the manufacturing sector (continuous line right y-axis) for the U.S. economy from 1947 to 2010. Data come from Jorgenson (2007) dataset.

data from the World Input-Output Database, which covers a panel of 38 countries over the years 1995 - 2011, we document that many world economies feature a process of services deepening as they develop. ${ }^{5}$ Figure 3 shows the relationship between the share of service inputs in either services or manufacturing and the logarithm of real GDP per capita across countries. In both graphs, we plot each country-year observation, for a total of 646 data points, together with the fitted polynomial regression line. The graphs show that countries with higher levels of GDP per-capita feature higher shares of service inputs in both manufacturing and services. ${ }^{6}$

\footnotetext{
${ }^{5}$ The countries are Australia, Austria, Belgium, Brazil, Bulgaria, Canada, China, Cyprus, Czech Republic, Denmark, Estonia, Finland, France, Germany, Greece, Hungary, India, Indonesia, Italy, Ireland, Japan, Korea, Latvia, Luxembourg, Malta, Mexico, the Netherlands, Poland, Portugal, Romania, Russia, Slovenia, Slovakia, Spain, Sweden, Turkey, the U.K. and the U.S.

${ }^{6}$ In Section A.1.1 of the Supplementary Appendix we use the cross-country data to run panel regressions and show that the share of service inputs increases with GDP per capita, even after controlling for other key characteristics such as financial development, trade openness, and human capital.
} 
Figure 3: Services Intermediate Inputs Across Countries.

(a) Service Industries

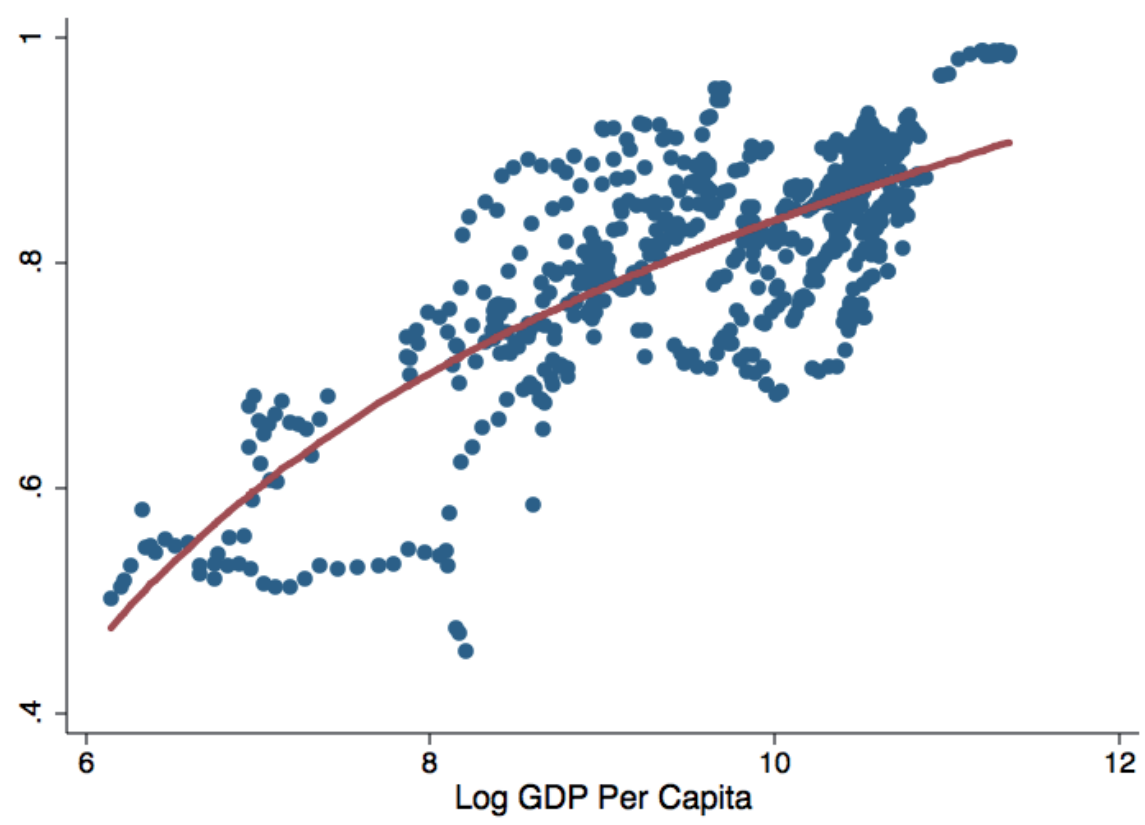

(b) Manufacturing Industries

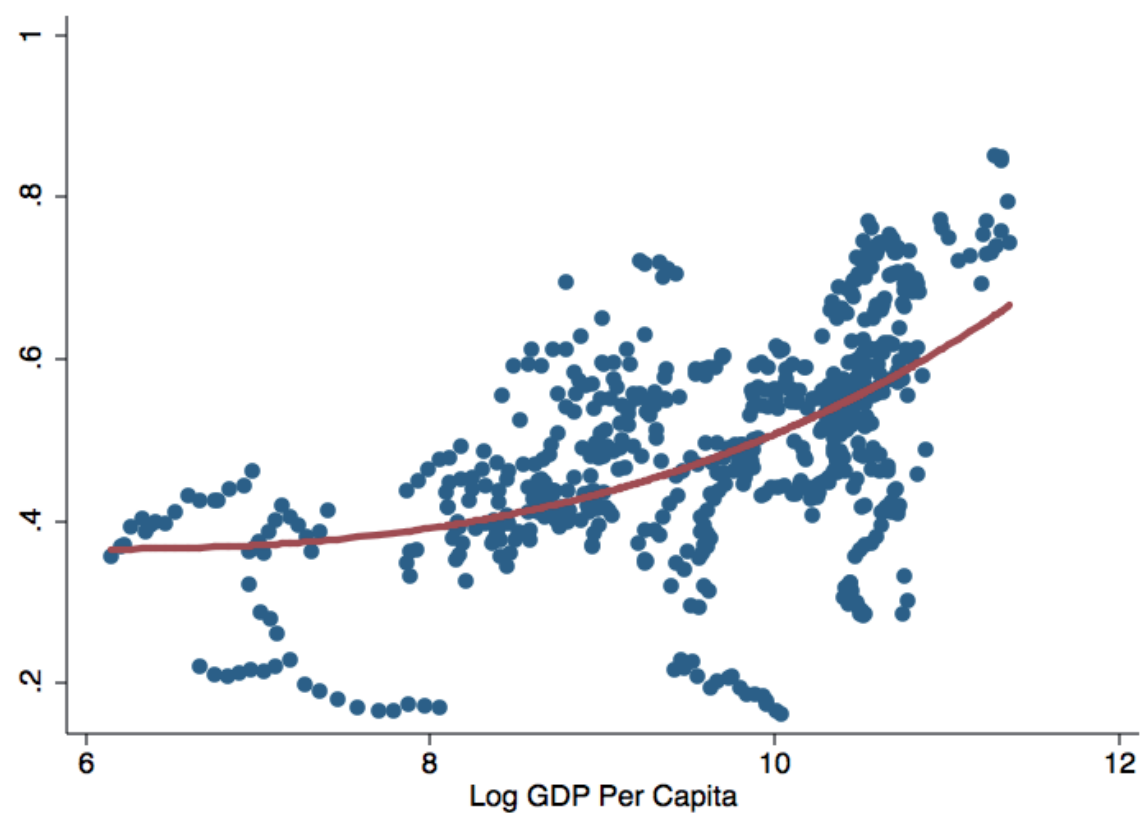

Note: Panel (a) plots country-year shares of service inputs in services as a function of the logarithm of the real GDP per capita. Panel (b) plots country-year shares of service inputs in manufacturing as a function of the logarithm of the real GDP per capita. The red line indicates the fitted quadratic polynomial regression line. Data come from the World Input-Output database and cover 38 countries from 1995 to 2011. 


\subsection{Price Stickiness in Services and Manufacturing}

Firms' price setting behavior differs substantially across sectors. Table 1 reports the average duration of services prices and manufacturing prices, as estimated by Bils and Klenow (2004), Klenow and Kryvtsov (2008) and Nakamura and Steinsson (2008). ${ }^{7}$ These authors find that services prices are much stickier than manufacturing prices: the median duration of a manufacturing prices is around 3 months, whereas the median duration of a services price ranges between 8 months and 13 months.

Table 1: Price Duration Across Sectors

\begin{tabular}{ccc}
\hline & Sector & Duration in Months \\
\hline Bils and Klenow (2004) & Services & 7.8 \\
Klenow and Kryvtsov (2008) & Manufacturing & 3.2 \\
& Services & 3.6 \\
Nakamura and Steinsson (2008) & Manufacturing & 3.4 \\
& Services & 3.8 \\
\hline
\end{tabular}

Why services prices are much stickier than manufacturing prices? The longer duration of prices in the service sector can be due to multiple factors: $(i)$ the share of labor in the gross output of services is almost twice as large as the share of labor in manufacturing. Since wages are very sticky, the higher labor share of services could imply that prices adjust less frequently; $(i i)$ since services are largely non-tradable whereas manufacturing goods are largely tradable, services are characterized by a lower degree of price competi-

\footnotetext{
${ }^{7}$ Bils and Klenow (2004) consider the micro data underlying the non-shelter components of the US Consumer Price Index from 1995 to 1997. Klenow and Kryvtsov (2008) and Nakamura and Steinsson (2008) study the micro data underlying the whole universe of items of the US Consumer Price Index from 1988 to 2005.
} 
tion. The higher mark-up could allow service firms to adjust less frequently their prices; (iii) durables goods are characterized by a frequent product turnover which is likely to increase the frequency of price adjustments.

The scope of our analysis is not to micro-found the asymmetry in the duration of prices across sectors. Rather, we consider a model with an exogenous price stickiness that differs across sectors. All the potential factors that can rationalize the different duration of prices across sectors are captured in a reduced form by differences in the parameter of price stickiness.

\section{The Model}

The economy is a version of a cashless Calvo staggered price New Keynesian model. We consider two sectors - services and manufacturing - which are connected through an Input-Output structure as in Bouakez et al. (2011): each sector produces output by using labor and a bundle of intermediate manufactured goods and services. The gross output in each sector is split into consumption goods and intermediate inputs.

The two sectors differ in the durability of the consumption good and the relative use of labor, service intermediate inputs and manufacturing intermediate inputs. Importantly, the two sectors differ also in the degree of price stickiness.

\subsection{Household}

The economy is populated by an infinitely-lived representative household that has preferences over the consumption of services $C_{t}^{s}$, the consumption of durable manufactured goods $D_{t}$, and labor $N_{t}$. The lifetime utility of the household equals

$$
\mathbb{E}_{0} \sum_{t=0}^{\infty} \beta^{t}\left(\frac{C_{t}^{1-\sigma}}{1-\sigma}-\psi \frac{N_{t}^{1+\gamma}}{1+\gamma}\right)
$$


with

$$
C_{t}=\left[\omega^{\frac{1}{\nu}} \times C_{t}^{s \frac{\nu-1}{\nu}}+(1-\omega)^{\frac{1}{\nu}} \times D_{t}^{\frac{\nu-1}{\nu}}\right]^{\frac{\nu}{\nu-1}}
$$

where $\beta$ is the discount factor, $\sigma$ is the inverse of the intertemporal elasticity of substitution, $\gamma$ is the inverse of the Frisch elasticity of labor supply, $\omega$ denotes the share of overall services in the CES aggregator and $\nu$ is the elasticity of substitution across services and manufactured goods.

The stock of manufactured goods $D_{t}$ follows the law of motion

$$
D_{t}=(1-\delta) D_{t-1}+C_{t}^{m}-\frac{\chi}{2}\left(\frac{C_{t}^{m}}{D_{t-1}}-\delta\right)^{2} D_{t-1}
$$

where $C_{t}^{m}$ denotes the purchase of new manufactured goods at time $t, \delta$ is the depreciation rate, and the last term on the right hand side captures convex adjustment costs, which depend on the parameter $\chi$.

The household maximizes lifetime utility (1) subject to the budget constraint

$$
P_{t}^{s} C_{t}^{s}+P_{t}^{m} C_{t}^{m}+B_{t}=W_{t} N_{t}+\left(1+i_{t-1}\right) B_{t-1}+\Pi_{t}^{s}+\Pi_{t}^{m}+T_{t}
$$

The household buys $C_{t}^{s}$ services at the nominal price $P_{t}^{s}$ and $C_{t}^{m}$ manufactured goods at the nominal price $P_{t}^{m}$. The household also invests in a one-period bond, denoted by $B_{t}$, which yields a nominal interest rate $i_{t}$. On the other side, the household earns a nominal labor income $W_{t} N_{t}$, and receives nominal profits from the service sector $\Pi_{t}^{s}$ and the manufacturing sector $\Pi_{t}^{m}$, and a lump-sum nominal transfer $T_{t}$.

The first-order conditions of the household's problem read

$$
\begin{gathered}
U_{C_{t}^{s}}=\frac{\omega^{\frac{1}{\nu}} C_{t}^{s-\frac{1}{\nu}} C_{t}^{\frac{1}{\nu}-\sigma}}{P_{t}^{s}} \\
U_{C_{t}^{s}}=\beta \mathbb{E}_{t}\left[\left(1+i_{t}\right) U_{C_{t+1}^{s}}\right]
\end{gathered}
$$




$$
\begin{gathered}
\psi N_{t}^{\gamma}=\frac{U_{C_{t}^{s}} w_{t}}{Q_{t}} \\
q_{D, t}=\left[1-\chi\left(\frac{C_{t}^{m}}{D_{t-1}}-\delta\right)\right]^{-1} \\
q_{D, t}=\frac{(1-\omega)^{\frac{1}{\omega}} D_{t}^{-\frac{1}{\omega}}}{U_{C_{t}^{s}}}+\beta \mathbb{E}_{t}\left[\frac { U _ { C _ { t + 1 } ^ { s } } } { U _ { C _ { t } ^ { s } } } q _ { D , t + 1 } \left\{(1-\delta)+\chi\left(\frac{C_{t+1}^{m}}{D_{t}}-\delta\right) \frac{C_{t+1}^{m}}{D_{t}}-\ldots\right.\right. \\
\left.\left.\cdots-\frac{\chi}{2}\left(\frac{C_{t+1}^{m}}{D_{t}}-\delta\right)^{2}\right\}\right]
\end{gathered}
$$

where Equation (5) determines the marginal utility of consumption of services $U_{C_{t}^{s}}$. Equation (6) defines the inter-temporal Euler condition for the consumption in services. Equation (7) governs the optimal supply of labor, while Equation (8) defines $q_{D, t}$ the relative price of the durable manufactured good in terms of overall consumption, that is, the marginal utility of adding one further unit to the stock of durable goods $D_{t}$. Equation (9) defines the inter-temporal Euler condition for the consumption of the durable manufactured goods, which takes into account the convex adjustment costs.

\subsection{Final Goods Firm}

As in standard New Keynesian models, the production side is split in two levels: in both the service sector and the manufacturing sector there is a competitive final goods firm and a continuum of intermediate goods firms. In particular, we consider a unit measure of service intermediate goods firms indexed by $i \in[0,1]$, whose value-added equals $Y_{i, t}^{s}$, and a unit measure of manufacturing intermediate goods firms indexed by $j \in[0,1]$, whose value-added equals $Y_{j, t}^{m}$.

In the service sector, the competitive final goods firms aggregate the different varieties produced by the continuum of intermediate goods firms using the CES function

$$
Y_{t}^{s}=\left(\int_{0}^{1} Y_{i, t}^{s \frac{\varepsilon-1}{\varepsilon}} d i\right)^{\frac{\varepsilon}{\varepsilon-1}}
$$


Analogously, in the manufacturing sector, the competitive final goods firms use the CES function

$$
Y_{t}^{m}=\left(\int_{0}^{1} Y_{j, t}^{m \frac{\varepsilon-1}{\varepsilon}} d j\right)^{\frac{\varepsilon}{\varepsilon-1}}
$$

The parameter $\varepsilon$ denotes the elasticity of substitution across different varieties of intermediate goods. The elasticity of substitution is constant across sectors.

Final good producers are perfectly competitive and take as given the price of the final good in each sector, $P_{t}^{s}, P_{t}^{m}$, and the price of each of the intermediates in each sector, $P_{i, t}^{s}, P_{i, t}^{m}$. As a result, the demand of each intermediate variety is isoelastic:

$$
Y_{i, t}^{s}=\left(\frac{P_{i, t}^{s}}{P_{t}^{s}}\right)^{-\varepsilon} Y_{t}^{s}
$$

and

$$
Y_{j, t}^{m}=\left(\frac{P_{j, t}^{m}}{P_{t}^{m}}\right)^{-\varepsilon} Y_{t}^{m}
$$

The combination of the isoelastic demand functions (12) and (13) with perfect competition among final goods producers makes the nominal price of the final goods in each sector to be combination of the nominal price of the intermediate varieties

$$
P_{t}^{s}=\left(\int_{0}^{1} P_{i, t}^{s 1-\varepsilon} d i\right)^{\frac{1}{1-\varepsilon}}
$$

and

$$
P_{t}^{m}=\left(\int_{0}^{1} P_{j, t}^{m 1-\varepsilon} d j\right)^{\frac{1}{1-\varepsilon}}
$$

\subsection{Intermediate Goods Firm}

In the service sector, each individual intermediate goods firm $i$ produces gross output using labor $N_{i, t}^{s}$ and intermediate inputs $I_{i, t}^{s}$ as follows

$$
G_{i, t}^{s}=A_{t}^{s}\left(N_{i, t}^{s}\right)^{\alpha_{s}}\left(I_{i, t}^{s}\right)^{1-\alpha_{s}}
$$


where $A_{t}^{s}$ denotes a sectoral-specific productivity shock and $\alpha_{s}$ is the share of labor in gross output. In the manufacturing sector, each individual intermediate goods firms $j$ produces gross output with a technology

$$
G_{j, t}^{m}=A_{t}^{m}\left(N_{j, t}^{m}\right)^{\alpha_{m}}\left(I_{j, t}^{m}\right)^{1-\alpha_{m}}
$$

where $A_{t}^{m}$ denotes a manufacturing-specific productivity shock and $\alpha_{m}$ is the share of labor in gross output. Importantly, we allow the shares of labor in the production function $\alpha_{s}$ and $\alpha_{m}$ to differ across sectors. This feature is meant to capture the fact that, in the data, services are more labor-intensive than manufacturing.

The intermediate inputs are modeled as a bundle of service inputs and manufacturing inputs. We consider a CES aggregator for both sectors:

$$
I_{i, t}^{s}=\left[\omega_{s}^{\frac{1}{\mu}}\left(S_{i, t}^{s}+\bar{s}_{s}\right)^{\frac{\mu-1}{\mu}}+\left(1-\omega_{s}\right)^{\frac{1}{\mu}}\left(M_{i, t}^{s}\right)^{\frac{\mu-1}{\mu}}\right]^{\frac{\mu}{\mu-1}}
$$

and

$$
I_{j, t}^{m}=\left[\omega_{m}^{\frac{1}{\mu}}\left(S_{j, t}^{m}+\bar{s}_{m}\right)^{\frac{\mu-1}{\mu}}+\left(1-\omega_{m}\right)^{\frac{1}{\mu}}\left(M_{j, t}^{m}\right)^{\frac{\mu-1}{\mu}}\right]^{\frac{\mu}{\mu-1}}
$$

The variable $S_{i, t}^{s}$ denotes the service intermediate inputs used in the production of gross output by the firm $i$ in the service sector at time $t$. Instead, $S_{j, t}^{m}$ denotes the service intermediate inputs used in the manufacturing sector. Analogously, $M_{i, t}^{s}$ and $M_{j, t}^{s}$ are the manufacturing intermediate inputs that are used in the production of gross output in the service sector and manufacturing sector, respectively. The parameters $\omega_{s}$ and $\omega_{m}$ denote the weight of service inputs in total service intermediates and manufacturing intermediates, respectively. We also add a non-homothetic component in each aggregator. This component changes across sectors: it equals $\bar{s}_{s}$ in the aggregator of service intermediates and $\bar{s}_{m}$ in the aggregator of manufacturing intermediates. Following the interpretation of Kongsamut et al. (2001), these parameters capture in a reduced form the amount of 
service inputs produced in-house by firms. The empirical evidence of Berlingieri (2014) on the marketization of firms' services justifies our modeling choice. Finally, $\mu$ defines the elasticity of substitution across service and manufacturing intermediates.

Each intermediate is a CES aggregator that compounds different varieties into a single input. The service inputs used in the service sector equal

$$
S_{i, t}^{s}=\left[\int_{0}^{1} S_{l, i, t}^{s}{ }^{\frac{\varepsilon-1}{\varepsilon}} d l\right]^{\frac{\varepsilon}{\varepsilon-1}}
$$

where $S_{l, i, t}^{s}$ denotes the service inputs produced by the service firm $l$ and used by the service firm $i$ at time $t$. The service inputs used in the manufacturing sector are

$$
S_{j, t}^{m}=\left[\int_{0}^{1} S_{l, j, t}^{m} \frac{\varepsilon-1}{\varepsilon} d l\right]^{\frac{\varepsilon}{\varepsilon-1}}
$$

Analogously, we define the manufacturing inputs used in both sectors as

$$
M_{i, t}^{s}=\left[\int_{0}^{1} M_{l, i, t}^{s} \frac{\frac{\varepsilon-1}{\varepsilon}}{d l}\right]^{\frac{\varepsilon}{\varepsilon-1}}
$$

and

$$
M_{j, t}^{m}=\left[\int_{0}^{1} M_{l, j, t}^{m} \frac{\varepsilon-1}{\varepsilon} d l\right]^{\frac{\varepsilon}{\varepsilon-1}}
$$

In each case, the elasticity of substitution is $\varepsilon$ as in the aggregator of the different varieties of the final goods.

Equations (18) and (19) jointly define the Input-Output matrix that links services and manufacturing. As pointed out in the literature, the role of the Input-Output matrix is a crucial ingredient for many reasons. First, it captures quantitatively relevant features of the data (Basu, 1995). Second, it amplifies the persistence of the effects arising from sectoral productivity and monetary policy shocks (Huang and Liu, 2005; Bouakez et al., 2009). Third, it allows monetary policy shocks to generate a positive co-movement in the reaction of sectoral output (Bouakez et al., 2011). Finally, it is an important determinant 
of the process of the structural change of an economy, which in turn affects the dynamics of key macroeconomic variables (Moro, 2012; Moro, 2015).

As we show in detail in Section 3.5, in our environment the Input-Output matrix varies endogenously over time as a function of relative sectoral productivities and the amount of output produced in the economy. As either the manufacturing productivity rises relative to the services one, or aggregate economic activity increases, the shares of service inputs used in manufacturing and services rise. This time-variation in the inter-sectoral network structure pins down the process of services deepening.

Given the production function (16) and (17), the cost minimization problem of intermediate firms implies the following first-order conditions for the optimal amount of labor to hire and the optimal amount of total intermediate inputs to purchase

$$
\begin{gathered}
N_{i, t}^{s}=\alpha_{s} M C_{t}^{s} \frac{G_{i, t}^{s}}{w_{t}} \\
I_{i, t}^{s}=\frac{\left(1-\alpha_{s}\right) M C_{t}^{s} G_{t}^{s}}{P_{t}^{I^{s}}} \\
N_{j, t}^{m}=\alpha_{m} M C_{t}^{m} \frac{G_{j, t}^{m}}{w_{t}} \\
I_{j, t}^{m}=\frac{\left(1-\alpha_{m}\right) M C_{t}^{m} G_{j, t}^{m}}{P_{t}^{I^{m}}}
\end{gathered}
$$

where $M C_{t}^{s}$ and $M C_{t}^{m}$ denote the real marginal cost for services and manufacturing intermediate goods producers, respectively. The price of the bundle of service intermediate inputs and the price of the bundle of manufacturing inputs equal respectively

$$
P_{t}^{I^{s}}=\left(\omega_{s} P_{t}^{s 1-\mu}+\left(1-\omega_{s}\right) P_{t}^{m 1-\mu}\right)^{\frac{1}{1-\mu}}
$$

and

$$
P_{t}^{I^{m}}=\left(\omega_{m} P_{t}^{s 1-\mu}+\left(1-\omega_{m}\right) P_{t}^{m 1-\mu}\right)^{\frac{1}{1-\mu}} .
$$


Given the intermediates aggregators (18) and (19), the first-order conditions on the decision between service intermediates and manufacturing intermediates read

$$
\begin{gathered}
S_{i, t}^{s}=\omega_{s}\left(\frac{P_{t}^{s}}{P_{t}^{I^{s}}}\right)^{-\mu} I_{i, t}^{s}-\bar{s}_{s} \\
M_{i, t}^{s}=\left(1-\omega_{s}\right)\left(\frac{P_{t}^{m}}{P_{t}^{I^{s}}}\right)^{-\mu} I_{i, t}^{s} \\
S_{j, t}^{m}=\omega_{m}\left(\frac{P_{t}^{s}}{P_{t}^{I^{m}}}\right)^{-\mu} I_{j, t}^{m}-\bar{s}_{m} \\
M_{j, t}^{m}=\left(1-\omega_{m}\right)\left(\frac{P_{t}^{m}}{P_{t}^{I^{m}}}\right)^{-\mu} I_{j, t}^{m}
\end{gathered}
$$

We assume that the sectoral productivity shocks follow stationary $\mathrm{AR}(1)$ processes

$$
\log A_{t}^{k}=\left(1-\rho_{k}\right) \log \bar{A}^{k}+\rho_{k} \log A_{t-1}^{k}+\epsilon_{t}^{k} \quad k \in\{s, m\}
$$

where $\bar{A}^{k}$ is the steady state value of the sectoral productivity and $\epsilon_{t}^{k}$ is an IID innovation to sectoral productivities such that $\epsilon_{t}^{k} \sim \operatorname{IID} N\left(0, \sigma_{\epsilon^{k}}\right)$.

With respect to the price settings, we assume that firms face a Calvo staggered price mechanism. In each period, a fraction $\phi_{s}$ of service intermediate goods producers and a fraction $\phi_{m}$ of manufacturing intermediate goods producers cannot reset prices, and maintain the price of the previous period. The fractions $\phi_{s}$ and $\phi_{m}$ are constant over time. Consequently, the optimal price setting problem of an intermediate goods producer in the service sector consists of maximizing the expected discounted stream of real dividends expressed in terms of the price of manufactured goods

$$
\max _{P_{i, t}^{s}} \mathbb{E}_{t} \sum_{r=t}^{\infty} \beta^{r} \phi_{s}^{r} \frac{U_{C_{t+r}^{s}}}{U_{C_{t}^{s}}} \frac{\Pi_{i, t+r}^{s}\left(P_{i, t}^{s}\right)}{P_{t+r}^{m}}
$$


where $\prod_{i, t}^{s}\left(P_{i, t}^{s}\right)$ denotes the nominal profits of the $i$-th firm in the service sector which sets its price to $P_{i, t}^{s}$ :

$$
\Pi_{i, t}^{s}\left(P_{i, t}^{s}\right)=(1+\tau) P_{i, t}^{s} G_{i, t}^{s}-W_{t} N_{i, t}^{s}-P_{t}^{s} S_{i, t}^{s}-P_{t}^{m} M_{i, t}^{s}
$$

Each firm maximizes the expected discounted stream of dividends of keeping in the future the current price $P_{i, t}^{s}$ with a probability $\phi_{s}$.

Similarly, an intermediate goods producer in the manufacturing sector maximizes

$$
\max _{P_{j, t}^{m}} \mathbb{E}_{t} \sum_{r=t}^{\infty} \beta^{r} \phi_{m}^{r} \frac{U_{C_{t+r}^{s}}}{U_{C_{t}^{s}}} \frac{\Pi_{j, t+r}^{m}\left(P_{j, t}^{m}\right)}{P_{t+r}^{m}}
$$

where $\Pi_{j, t}^{m}\left(P_{j, t}^{m}\right)$ denotes the nominal profits

$$
\Pi_{j, t}^{m}\left(P_{j, t}^{m}\right)=(1+\tau) P_{j, t}^{m} G_{j, t}^{m}-W_{t} N_{j, t}^{m}-P_{t}^{s} S_{j, t}^{m}-P_{t}^{m} M_{j, t}^{m}
$$

Note that we also assume that firms receive a subsidy to the overall production $\tau=\frac{1}{\varepsilon}$, which is meant to offset their market power.

Then, the optimal reset price for a service firm $P_{t}^{\star, s}$ and the optimal reset price for a manufacturing firm $P_{t}^{\star, m}$ equal respectively

$$
P_{t}^{\star, s}=\frac{\varepsilon}{\varepsilon-1} \frac{\mathbb{E}_{t} \sum_{r=t}^{\infty} \beta^{r} \phi_{s}^{r} \frac{U_{C_{t+r}^{s}}}{U_{C_{t}^{s}}} \frac{\lambda_{t+r}^{s}}{P_{t+r}^{m}}\left(P_{t+r}^{s}\right)^{\varepsilon}\left(Y_{t+r}^{s}+S_{t+r}^{s}+S_{t+r}^{m}\right)}{\mathbb{E}_{t} \sum_{r=t}^{\infty} \beta^{r} \phi_{s}^{r} \frac{U_{C_{t+r}^{s}}}{U_{C_{t}^{s}}^{s}}(1+\tau)\left(P_{t+r}^{s}\right)^{\varepsilon}\left(Y_{t+r}^{s}+S_{t+r}^{s}+S_{t+r}^{m}\right)}
$$

and

$$
P_{t}^{\star, m}=\frac{\varepsilon}{\varepsilon-1} \frac{\mathbb{E}_{t} \sum_{r=t}^{\infty} \beta^{r} \phi_{m}^{r} \frac{U_{C_{t+r}^{s}}}{U_{C_{t}^{s}}} \frac{\lambda_{t+r}^{m}}{P_{t+r}^{m}}\left(P_{t+r}^{m}\right)^{\varepsilon}\left(Y_{t+r}^{m}+M_{t+r}^{s}+M_{t+r}^{m}\right)}{\mathbb{E}_{t=t}^{\infty} \beta^{r} \phi_{m}^{r} \frac{U_{C_{t+r}^{s}}}{U_{C_{t}^{s}}^{s}}(1+\tau)\left(P_{t+r}^{m}\right)^{\varepsilon}\left(Y_{t+r}^{m}+M_{t+r}^{s}+M_{t+r}^{m}\right)}
$$

The Calvo friction together with the optimal price setting conditions derived in (39) and (40) imply that sectoral prices evolve as

$$
P_{t}^{s}=\left[\left(1-\phi_{s}\right)\left(P_{t}^{\star, s}\right)^{1-\varepsilon}+\phi_{s}\left(P_{t-1}^{s}\right)^{1-\varepsilon}\right]^{\frac{1}{1-\varepsilon}}
$$


and

$$
P_{t}^{m}=\left[\left(1-\phi_{m}\right)\left(P_{t}^{\star, m}\right)^{1-\varepsilon}+\phi_{m}\left(P_{t-1}^{m}\right)^{1-\varepsilon}\right]^{\frac{1}{1-\varepsilon}}
$$

\subsection{Closing the Model}

In any time period, the aggregate nominal GDP equals the sum of the nominal services value added and the nominal manufacturing value added, that is

$$
P_{t} Y_{t}=P_{t}^{s} Y_{t}^{s}+P_{t}^{m} Y_{t}^{m}
$$

We follow the same definition used by NIPA to compute the series of real GDP. We set the real aggregate GDP by fixing constant base year-prices. In particular, we normalize the base-year prices to one, such that the aggregate real GDP reads

$$
Y_{t}=\bar{P}^{s} Y_{t}^{s}+\bar{P}^{m} Y_{t}^{m}=Y_{t}^{s}+Y_{t}^{m}
$$

The aggregate price level is then derived as a GDP deflator, obtained by computing the ratio of nominal GDP to real GDP

$$
P_{t}=\frac{P_{t}^{s} Y_{t}^{s}+P_{t}^{m} Y_{t}^{m}}{Y_{t}}
$$

so that the aggregate inflation rate equals $1+\pi_{t}=\frac{P_{t}}{P_{t-1}}$.

To close the model, we define the Taylor rule as

$$
\frac{1+i_{t}}{1+\bar{i}}=\left(\frac{1+i_{t-1}}{1+\bar{i}}\right)^{\rho_{i}}\left[\left(1+\pi_{t}\right)^{\phi_{\pi}}\left(x_{t}\right)^{\phi_{y}}\right]^{1-\rho_{i}} \exp \left(\epsilon_{t}^{r}\right)
$$

where $x_{t}$ defines the output gap, that is $x_{t}=\log \left(\frac{Y_{t}}{Y_{t}^{F L E X}}\right)$ where $Y_{t}^{F L E X}$ is real GDP of the economy with fully flexible prices, $\bar{i}$ denotes the steady-state interest rate, $\rho_{i}$ captures the degree of the inertia in the nominal interest rate, $\phi_{\pi}$ and $\phi_{y}$ define the elasticity at 
which monetary authorities adjust the interest rate due to movements in the current inflation rate and output gap, respectively, and $\epsilon_{t}^{r}$ is an IID monetary policy shock such that $\epsilon_{t}^{r} \sim \operatorname{IIDN}\left(0, \sigma_{\epsilon^{r}}\right)$.

With respect to the production subsidy, the total amount of resources allocated to firms is financed through a lump-sum tax applied to the households such that

$$
-T_{t}=\int_{0}^{1} \tau P_{i, t}^{s} G_{i, t}^{s} d i+\int_{0}^{1} \tau P_{j, t}^{m} G_{j, t}^{m} d j
$$

Finally, in a symmetric equilibrium the market-clearing conditions for final services and final manufactured goods are

$$
\begin{gathered}
C_{t}^{s}=Y_{t}^{s}=\left[\int_{0}^{1} Y_{i, t}^{s \frac{\varepsilon-1}{\varepsilon}} d i\right]^{\frac{\varepsilon}{\varepsilon-1}} \\
C_{t}^{m}=Y_{t}^{m}=\left[\int_{0}^{1} Y_{j, t}^{m \frac{\varepsilon-1}{\varepsilon}} d j\right]^{\frac{\varepsilon}{\varepsilon-1}}
\end{gathered}
$$

The market-clearing conditions for the intermediate firms posit that gross output should be allocated between the intermediate inputs provided to either sector and the different varieties of final goods provided to the final good firms, that is

$$
\int_{0}^{1} G_{i, t}^{s} d i=\int_{0}^{1} S_{i, t}^{s} d i+\int_{0}^{1} S_{j, t}^{m} d j+\int_{0}^{1} Y_{i, t}^{s} d i
$$

and

$$
\int_{0}^{1} G_{j, t}^{m} d j=\int_{0}^{1} M_{i, t}^{s} d i+\int_{0}^{1} M_{j, t}^{m} d j+\int_{0}^{1} Y_{j, t}^{m} d j
$$

The last market-clearing condition refers to the labor market, and states that the total labor supplied by the households equals the sum of the amount of labor demanded by the service sector and the manufacturing sector,

$$
N_{t}=N_{t}^{s}+N_{t}^{m}=\int_{0}^{1} N_{i, t}^{s} d i+\int_{0}^{1} N_{j, t}^{m} d j
$$




\subsection{Characterizing the Process of Services Deepening}

In the literature the Input-Output matrix is considered as constant over time because the share of total intermediate inputs in the value added of firms is rather stable. Nevertheless, the dynamics of total intermediate inputs mask a large sectoral reallocation that works through the process of services deepening. To capture the sectoral shifts in the composition of intermediate inputs, we propose a mechanism that generates an endogenous variation of the Input-Output matrix through two channels:

(i) a Baumol (1967) cost disease channel that raises the share of service inputs when the relative productivity of manufacturing rises, as in Ngai and Pissarides (2007);

(ii) the marketization of firms' services which raises the share of service inputs when output increases, due to the non-homotheticities in the intermediate aggregators.

We characterize analytically the sources of services deepening in both services and manufacturing. For ease of exposition we make the following assumptions: $(i)$ in each sector the elasticity of substitution across varieties equals the inverse of the subsidy to production, that is, $\varepsilon=1 / \tau ;(i i)$ the weight given to service inputs in the CES aggregator of intermediates is the same across sectors, that is, $\omega_{s}=\omega_{m}=\omega$; ( $\left.i i i\right)$ the gross output of both sectors is just a function of productivities and intermediates, that is, $\alpha_{s}=\alpha_{m}=0$. Given these assumptions, in the steady-state the share of service inputs in services and manufacturing equal respectively

$$
\frac{P^{s} S^{s}}{P^{I^{s} I^{s}}}=\frac{\omega Z^{1-\mu}}{\omega Z^{1-\mu}+(1-\omega)}-\frac{\bar{s}_{s}}{A^{s}}\left(\omega+\frac{1-\omega}{Z^{1-\mu}}\right)
$$

and

$$
\frac{P^{s} S^{m}}{P^{I^{m}} I^{m}}=\frac{\omega Z^{1-\mu}}{\omega Z^{1-\mu}+(1-\omega)}-\frac{\bar{s}_{m}}{A^{m}}\left(\omega+\frac{1-\omega}{Z^{1-\mu}}\right)
$$

where $Z=A^{m} / A^{s}$ denotes the relative productivity of manufacturing in terms of the productivity of services. Equations (47) and (48) show that the share of service inputs 
in both sector depends on two components. The first one highlights the contribution of the Baumol disease channel and the second one captures the variation due to the non-homothetic components.

First, let us abstract from the non-homothetic components by setting $\bar{s}_{s}=\bar{s}_{m}=0$. In this case, the shares of service inputs are the same across sectors and depend on the weight of service inputs in the CES aggregators $\omega$, the relative productivity of manufacturing $Z$, and the elasticity of substitution between service inputs and manufacturing inputs $\mu$. As long as manufacturing and service intermediates are relatively poor substitutes (i.e. $\mu<1$ ), an increase in the relative productivity of manufacturing raises the share of service inputs:

$$
\frac{\partial\left(\frac{P^{s} S^{s}}{P^{S} I^{s}}\right)}{\partial Z}=\frac{\partial\left(\frac{P^{s} S^{m}}{P^{I^{m}} I^{m}}\right)}{\partial Z}=\frac{\partial\left(\frac{\omega Z^{1-\mu}}{\omega Z^{1-\mu}+(1-\omega)}\right)}{\partial Z}>0
$$

This derivative captures the Baumol cost disease channel, in which relative productivities affect the sectoral allocation of inputs by changing the relative price across sectors. ${ }^{8}$

Now let us abstract from movements in relative productivities by setting $Z=1$, such that $A^{s}=A^{m}=A$. In this case, the share of service inputs in services equals

$$
\frac{P^{s} S^{s}}{P^{I^{s}} I^{s}}=\omega-\frac{\bar{s}_{s}}{A}
$$

and the share of service inputs in manufacturing equals

$$
\frac{P^{s} S^{m}}{P^{I^{m}} I^{m}}=\omega-\frac{\bar{s}_{m}}{A}
$$

These conditions posit that the shares of service inputs in both sectors are inversely related to the non-homothetic components $\bar{s}_{s}$ and $\bar{s}_{m}$. Nevertheless, when productivity

\footnotetext{
${ }^{8}$ The service share increases with the relative productivity $Z$ if $\mu<1$. Although there is no estimate of $\mu$, the literature has extensively documented that the analogous elasticity in the consumption bundle of the households is well below unity. Duarte and Restuccia (2010) consider an elasticity of substitution of 0.8 while Herrendorf et al. (2013) estimate a value as low as 0.002. We conjecture that also manufacturing inputs and service inputs are weak substitutes because firms cannot easily replace a consultant with some manufacturing goods. Hence, we think that the empirically relevant value of the elasticity of substitutions between services and manufacturing inputs is $\mu<1$.
} 
rises, the negative contribution of the non-homothetic components vanishes over time. In this way, an increase in output leads to a switch towards service inputs even in the absence of movements in the relative productivities. ${ }^{9}$

\section{Quantitative Analysis}

\subsection{Calibration}

We group the model parameters to be calibrated in two sets. The first set of parameters is calibrated as in standard New Keynesian models, with the unique difference that we consider two inter-connected sectors. The second set of parameters is calibrated such as to match the changes in the share of service inputs experienced by the U.S. economy from 1947 to 2005. In this way, the model can fully account for the process services deepening observed in the U.S. economy over the last six decades. Throughout the exercises of the paper, we fix one period of the model to coincide with a quarter.

Table 2 reports the first set of parameters. We choose the parameters of the utility function such that the inverse of the elasticity of intertemporal substitution is $\sigma=2$ and the inverse of the Frisch elasticity is $\gamma=1$, which are standard values in the literature. The relative disutility of labor is set to $\psi=15.7828$ to match a steady-state labor of $\bar{N}=0.33$. We set the time discount parameter to $\beta=0.995$ to have a steady-state annual inflation rate of $2 \%$. We set the elasticity of substitution between services and manufacturing in consumption to $\nu=0.4$. Although this value is slightly lower than the 0.8 used in Duarte and Restuccia (2007), our choice is anyway much higher than the value of $\nu=0.002$ that Herrendorf et al. (2013) find in consumption expenditure data. We set the elasticity of substitution between services and manufacturing inputs as $\mu=0.4$ to equalize the elasticity of substitution on the consumption side.

\footnotetext{
${ }^{9}$ The non-homothetic parameters are not crucial for our quantitative results: sectoral reallocation dampens the response of inflation even in a model without the non-homothetic parameters. The only rationale for these components is to allow the model to be able to match the entire variation in the Input-Output matrix observed in the data.
} 
The depreciation rate of the manufactured good is set to $\delta=0.154$. This value is much higher than the standard quarterly depreciation rate of 0.025 for durable goods. Yet, from 1947 to 2005 around $60 \%$ of the manufactured goods were durable while the remaining $40 \%$ were non-durable. These shares are rather constant over time. Averaging out these values imply an average quarterly depreciation rate of 0.154 .

The adjustment cost parameter is calibrated to match the relative contemporaneous response of manufacturing output with respect to services output to a monetary policy shock. To do so, we run a SVAR model with services inflation, services output, manufacturing inflation, manufacturing output and nominal interest rates. For the sectoral variables, we consider data on sectoral personal consumption expenditures from the $\mathrm{Bu}-$ reau of Economic Analysis from 1947Q1 to 2005Q4. We identify monetary policy shocks using sign restrictions by assuming that a monetary policy shock raises on impact (and the following quarter) the nominal interest rate, and decreases sectoral outputs and inflation rates. We find that the contemporaneous response of manufacturing output is 2.435 times as large as the one of service output. Accordingly, we set the adjustment parameter to $\chi=2.4602$.

We set both the elasticity of substitution across intermediate goods in both the service sector and manufacturing sector to $\varepsilon=6$, which is the value estimated both in Christiano et al. (2005) and Christiano et al. (2011).

With respect to the calibration of the parameters of the Cobb-Douglas technology, we discipline our choices using data from the 35-sector Jorgenson (2007) database on sectoral value added and sectoral intermediate inputs value over the period 1947 to 2005. First, we derive from the data a model consistent definition of gross output, which sums the labor compensation to the compensation of intermediate inputs. Then, we compute the average share of intermediates in gross output over the sample period for both sectors. For manufacturing, the share of intermediates on value added equals 0.7098. This value implies a labor share for manufacturing that equals $\alpha_{m}=0.2902$. For services, the share of intermediates on value added equals 0.4721 , which implies a labor share of $\alpha_{s}=0.5279$. 
Table 2: Calibrated Parameters

Parameter

Elasticity Intertemporal Substitution

Inverse Frisch elasticity

Relative Disutility of Labor

Elasticity of Substitution Consumption

Elasticity of Substitution Inputs

Time discount

Depreciation Rate Manufacturing

Adjustment Cost

Elasticity of Substitution Intermediate Goods

Labor Share Services

Labor Share Manufacturing

Calvo Frequency Services

Calvo Frequency Manufacturing

Interest Rate Inertia

Taylor Parameter Inflation

Taylor Parameter Output Gap

Auto-Correlation Productivity Services

Auto-Correlation Productivity Manufacturing

Standard Deviation Productivity Services

Standard Deviation Productivity Manufacturing

Standard Deviation Monetary Policy Shock

\section{Value}

$\sigma=2$

$\gamma=1$

$\psi=15.7828$

$\nu=0.4$

$\mu=0.4$

$\beta=0.995$

$\delta=0.1$

$\chi=2.4602$

$\varepsilon=6$

$\alpha_{s}=0.5279$

$\alpha_{m}=0.2902$

$\phi_{s}=0.7788$

$\phi_{m}=0.3679$

$\rho_{i}=0.8$

$\phi_{\pi}=1.5$

$\phi_{\pi}=0.2$

$\rho_{s}=0.9$

$\rho_{m}=0.9$

$\sigma_{\epsilon^{s}}=0.1$

$\sigma_{\epsilon} m=0.1$

$\sigma_{\epsilon^{r}}=0.1$
Target/Source

Standard value

Standard value

Steady-State Labor $=0.33$

Standard value

Elasticity of Substitution Consumption

Steady-State Annual Interest Rate $=0.02$

Avg. Depreciation of Manufactured Goods

Output Response to Monetary Policy Shock

Standard value

Intermediates Share Services

Intermediates Share Manufacturing

Duration of Prices of 12 Months

Duration of Prices of 3 Months

Standard Value

Standard Value

Standard Value

Standard Value

Standard Value

Standard Value

Standard Value

Standard Value 
For the price friction, we follow the evidence of Bils and Klenow (2004), Klenow and Kryvtsov (2008) and Nakamura and Steinsson (2008), who point out that the median duration of prices in the service sector ranges between 8 months and 13 months, while manufactured goods have a much lower duration of 3.2 months. Accordingly, we set $\phi_{s}=0.7788$ for services firms, which implies an average duration of 12 months, and $\phi_{m}=0.3679$ for manufacturing firms, which implies an average duration of 3 months. ${ }^{10}$

We set the parameters of the Taylor rule following the estimates of Clarida et al. (2000), which have become standard reference values in the literature. We set the inertia in nominal interest rate to $\rho_{i}=0.8$, the Taylor rule coefficients of inflation and output gap are set to $\phi_{\pi}=1.5$ and $\phi_{y}=0.2$, respectively. Finally, the autocorrelation coefficients of sectoral productivity shocks are set to $\rho_{s}=\rho_{m}=0.9$, and the standard deviations of all the shocks are set to $\sigma_{\epsilon^{s}}=\sigma_{\epsilon^{m}}=\sigma_{\epsilon^{r}}=0.1$.

Then, we report in Table 3 the parameters that discipline the amount of services deepening in the model. There are seven parameters to calibrate: the weight of services in the consumption aggregator $\omega$, the weight of services in the aggregator of service inputs $\omega_{s}$, the value of in-house production of service inputs in services $\bar{s}_{s}$, the weight of services in the aggregator of manufacturing inputs $\omega_{m}$, the value of in-house production of service inputs in manufacturing $\bar{s}_{m}$, the levels of the productivity of manufacturing $\bar{A}^{m}$ and services $\bar{A}^{s}$ in the 1947-model and in the 2005-model.

First, we compute gross output productivities using data from the 35-sector Jorgenson (2007) dataset. Then we normalize the productivities in 1947 to unity. This procedure yields 2005 productivity values of $\bar{A}^{s}=1.2675$ for services and $\bar{A}^{m}=1.6941$ for manufacturing. We calibrate the remaining five parameters to match five moments: the share of service value added in 1947 (68.9\%), the share of service inputs in services in 1947

\footnotetext{
${ }^{10}$ The implied aggregate duration of prices, once averaging sectoral durations using the equilibrium value added shares, equals 7 months in the 1947 equilibrium and 9 months in the 2005. These values correspond to impliedaggregate Calvo parameters of 0.65 and 0.72 , which are in line with the values typically estimated in the literature.
} 
Table 3: Calibration Parameters Structural Transformation \& Services Deepening

$\begin{array}{lll}\text { Parameter Value } \quad \text { Target/Source } & \text { Val }\end{array}$

Weight Services Consumption Aggregator

Weight Services Inputs for Services

Weight Services Inputs for Manufacturing

In-House Production Service Inputs in Services

In-House Production Service Inputs in Manufacturing

Level Productivity Services

Level Productivity Manufacturing

$$
\begin{gathered}
\omega=0.4677 \\
\omega_{s}=0.8688 \\
\omega_{m}=0.4729 \\
\bar{s}_{s}=0.0321
\end{gathered}
$$$$
\bar{s}_{m}=0.0167
$$$$
\bar{A}^{s}=1.2675
$$

$\bar{A}^{m}=1.6941$
Share Service Value Added in 1947

Share Service Inputs in Services in 1947

Share Service Inputs in Manufacturing in 1947

Share Service Inputs in Services in 2005

Share Service Inputs in Manufacturing in 2005

Productivity Services in 2005 Services Productivity in $1947=1$

Productivity Manufacturing in 2005 Manufacturing Productivity in $1947=1$

(61.5\%), the share of service inputs in services in 2005 (83.6\%), the share of service inputs in manufacturing in 1947 (20.0\%) and the share of service inputs in manufacturing in $2005(33.6 \%)$. In this way, we find $\omega=0.4677, \omega_{s}=0.8688, \bar{s}_{s}=0.0321, \omega_{m}=0.4729$ and $\bar{s}_{m}=0.0167 .^{11}$ Although the model is not calibrated to match the process of structural change, it succeeds in explaining around half of the rise in the service share of GDP (i.e., in the model the service share of GDP raises from $68.9 \%$ to $76.1 \%$, while in the data it raises from $68.9 \%$ to $85.2 \%$ ).

\subsection{The Response to Monetary Policy Shocks}

What are the effects of structural change and services deepening on the transmission of monetary policy? Our theory predicts that the process of sectoral reallocation reduces the response of inflation to monetary policy shocks through two channels:

\footnotetext{
${ }^{11}$ Section A.2 of the Supplementary Appendix reports the results of an accounting exercise on the sources of the variation in the Input-Output matrix across the two steady-states.
} 
(i) Structural transformation work via a composition channel which raises the relative importance of services, that have stickier prices than manufacturing. Given that the 2005 economy features a higher share of services, aggregate inflation becomes stickier and less reactive to monetary policy shocks.

(ii) Services deepening propagates through a marginal cost channel that affects the behavior of each individual firm in either sector. By increasing the relative usage of service inputs, the process of services deepening affects firms' marginal costs, which become stickier. The dynamics of marginal costs spill over to sectoral prices, which also become stickier and less reactive to monetary policy shocks.

We study the quantitative relevance of these two mechanisms. We compare the response of inflation to monetary policy shocks, over the steady-states in 1947 and 2005. The two equilibria differ only in the levels of sectoral productivities. Throughout our exercise, we keep fixed all the other parameters, included those of the Taylor rule. In this way, we can ask to what extent structural change and services deepening alone can alter the transmission of monetary policy shocks. ${ }^{12}$ To disentangle the relative role of structural change versus services deepening, we also compare the same steady-states in an alternative economy which abstracts from the process of services deepening. Namely, we consider an economy in which the sectoral shares of intermediate inputs are constant over time and calibrated to the average shares observed between 1947 and $2005 .{ }^{13}$

Table 4 reports the contemporaneous reaction of inflation, marginal costs and output to a positive monetary policy shock in 1947 and 2005 (respectively columns 1 and 2), the ratio of 2005-response over 1947-response (column 3), and the same ratio for the counterfactual economy which does not feature services deepening (column 4).

\footnotetext{
${ }^{12}$ We consider the monetary policy of the 1947 steady-state as described by a Taylor rule to define a counterfactual economy, in which everything is similar to the 2005 steady-state but for both the level of sectoral productivities and the shares of services in GDP and intermediate inputs. Our choice only aims at identifying the effects of sectoral reallocation on the transmission of monetary policy, keeping constant the way monetary policy is carried out.

${ }^{13}$ The average share of services inputs used by the service sector from 1947 to 2005 equals $69.8 \%$. For manufacturing, the analogous average share equals $27.1 \%$.
} 
Table 4 shows that prices in services respond less than in manufacturing: the response of manufacturing inflation is thrice as large as the response of services inflation, both in 1947 and in 2005. Consequently, when moving from the 1947 steady-state to the 2005 one, the rise of services reduces the reaction of aggregate inflation by about $37 \%$, from $-0.31 \%$ to $-0.19 \%$. Figure 4 shows how the response of inflation becomes more sluggish over time. Instead, when we shut down the process of services deepening, by considering an economy with a constant Input-Output matrix, the reduction of the response of aggregate inflation equals just $26 \%$. Hence, services deepening accounts for one third of the reduction in the response of aggregate inflation to a monetary policy shock. ${ }^{14}$

Figure 4: The Response of Aggregate Inflation to Monetary Policy Shocks.

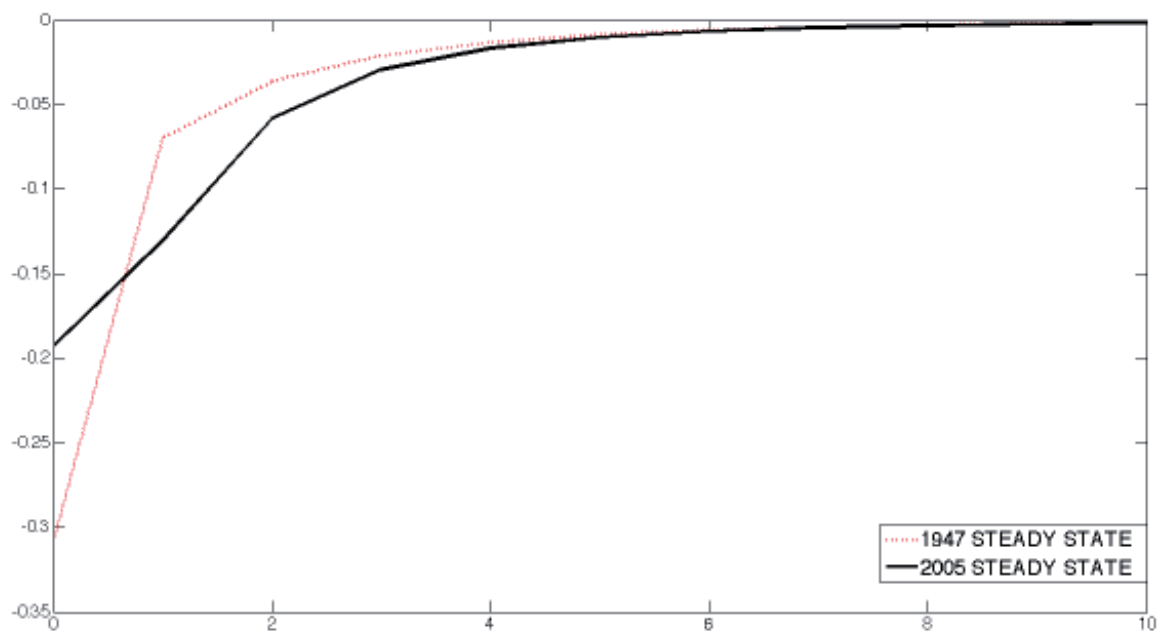

The figure shows the response of aggregate inflation to a positive monetary policy shock in the 1947 steady-state (dashed line) and in the 2005 steady-state (continuous line).

The process of sectoral reallocation also reduces the contemporaneous response of sectoral inflation rates. Over the two steady-states, the reaction of services inflation shrinks by $7 \%$ (from $-0.17 \%$ to $-0.16 \%$ ), and the reaction of manufacturing inflation decreases by

\footnotetext{
${ }^{14}$ In the Supplementary Appendix we show that the results on the role of sectoral composition on the transmission of monetary policy are consistent with the impulse-response functions derived by a SVAR on a panel of US states. We group the states in two sets, depending on the shares of services in GDP (i.e., a first set of states with high shares of services and a second set of states with low shares of services). We identify monetary policy shocks using sign restriction, and compare the response of inflation and output to a monetary policy shock in the two panels of states.
} 
Table 4: Contemporaneous Response of Inflation and Output to Monetary Policy Shock

\begin{tabular}{ccccc}
\hline & & Benchmark Economy & & $\begin{array}{c}\text { Counterfactual Economy without } \\
\text { Services Deening }\end{array}$ \\
& Model 1947 & Model 2005 & $\begin{array}{c}\text { Ratio } \\
2005 / 1947\end{array}$ & $\begin{array}{c}\text { Ratio } \\
2005 / 1947\end{array}$ \\
\hline$\pi_{t}$ & $-0.31 \%$ & $-0.19 \%$ & 0.63 & 0.74 \\
$\pi_{t}^{s}$ & $-0.17 \%$ & $-0.16 \%$ & 0.93 & 0.98 \\
$\pi_{t}^{m}$ & $-0.49 \%$ & $-0.44 \%$ & 0.90 & 0.99 \\
$M C_{t}^{s}$ & $-0.68 \%$ & $-0.63 \%$ & 0.93 & 0.99 \\
$M C_{t}^{m}$ & $-0.35 \%$ & $-0.31 \%$ & 0.89 & 0.99 \\
$Y_{t}$ & $-0.57 \%$ & $-0.63 \%$ & 1.10 & 1.05 \\
$Y_{t}^{s}$ & $-0.43 \%$ & $-0.44 \%$ & 1.03 & 1.01 \\
$Y_{t}^{m}$ & $-1.00 \%$ & $-1.08 \%$ & 1.08 & \\
\hline
\end{tabular}

Note: The entries report the contemporaneous response (in log-deviations from the steady-state) of each variable to a positive $1 \%$ monetary policy shock, equivalent to an increase of 30 basis points in the nominal interest rate. $\pi_{t}$ denotes the aggregate inflation rate, $\pi_{t}^{s}$ is the inflation rate of services, $\pi_{t}^{m}$ is the inflation rate of manufacturing, $M C_{t}^{s}$ is the real marginal cost of services, $M C_{t}^{m}$ is the real marginal cost of manufacturing, $Y_{t}$ denotes the aggregate output growth, $Y_{t}^{s}$ is the output growth of services and $Y_{t}^{m}$ is the output growth of manufacturing. "Benchmark Economy" refers to the economy with both structural transformation and services deepening. "Model 1947" refers to the equilibrium calibrated to the shares of services in intermediates observed in the U.S. in 1947. "Model 2005" refers to the equilibrium calibrated to the shares of services in intermediates observed in the U.S. in 2005. "Model 1947" and "Model 2005" differ just in the values of sectoral productivities. "Counterfactual Economy without Services Deepening" refers to the equilibrium in which the intermediates aggregators are Cobb-Douglas functions and there is no non-homothetic component, that is, $\mu=1$ and $\bar{s}_{s}=\bar{s}_{m}=0$. We calibrate the shares of service inputs in services and manufacturing to the average values observed between 1947 and 2005. The levels of TFP in the counterfactual economy are model-consistent. 
$10 \%$ (from $-0.49 \%$ to $-0.44 \%$ ). The drop in the reaction of sectoral prices is mirrored by the fall in the reactions of sectoral marginal costs, which decrease by about $7 \%$ in services and $11 \%$ in manufacturing. Without services deepening, the responses of sectoral inflation barely change. These findings point out that, while structural transformation reduces the reaction of aggregate inflation mainly through a composition effect, services deepening acts through a marginal cost channel which affects sectoral inflation rates.

When looking at the response of output, Table 4 displays that monetary policy shocks nowadays have slightly larger real effects. Over the two steady-states, the reaction of aggregate output rises by $10 \%$, while the reaction of service output and manufacturing output increases by $3 \%$ and $8 \%$, respectively. Abstracting from the services deepening halves the increase in the real effects of monetary policy.

Why do monetary policy shocks have larger real effects? Sectoral reallocation shifts economic activities towards services, whose prices are much stickier than manufacturing prices. Hence, the rise of services raises the average duration of prices in the economy. As prices get stickier, inflation reacts less to shocks, and movements in the nominal interest rate are less neutral for output. This mechanism explains why monetary policy shock have larger effects on output, at the cost of a lower influence on the dynamics of inflation. ${ }^{15}$ Importantly, our mechanism is consistent with the empirical evidence on the evolution of the degree of price stickiness at both the micro-level and aggregate-level. On the one hand, model-based estimation of the Calvo parameter points out to an increase in the average duration of prices (e.g., Smets and Wouters, 2007; Fernandez-Villaverde and Rubio-Ramirez, 2007). On the other hand, the frequency of price adjustments based on micro data has not changed substantially over time (e.g., Bils and Klenow, 2008). In our model, the duration of prices at the sectoral level is kept constant. Yet, as the economy shifts towards services, the implied average duration of prices raises over time.

\footnotetext{
${ }^{15}$ The asymmetry in the degree of price stickiness across sectors is crucial for our results. Without it, a shift from manufacturing to services would actually increase the response of inflation to a monetary policy shock. Since the share of intermediate inputs in the gross output of the manufacturing sector is as twice as large than in the services sector, the sectoral reallocation towards services would raise the flexibility of prices, by reducing the mechanism of strategic complementarities emphasized by Nakamura and Steinsson (2010). Section A.3.1 of the Supplementary Appendix shows the effects of the sectoral reallocation in an economy in which price stickiness is common across sectors.
} 
Overall we show that the process of sectoral reallocation alters the response of inflation and output to monetary policy shocks. These results add to the extensive literature studying the changes in the transmission of monetary policy over time, such as Cogley and Sargent (2001, 2005), Primiceri (2005), Boivin and Giannoni (2006) and Pancrazi and Vukotic (2016), among others. For instance, Boivin and Giannoni (2006) and Pancrazi and Vukotic (2016) find a reduction in the response of inflation to monetary policy shocks in the post-1980 period. These papers rationalize the variation in the response to monetary policy shocks with changes in either policy or the volatility of shocks. We complement this strand of the literature by providing a novel channel that can generate low-frequency movements in the effectiveness of monetary policy. Since in our model neither the Taylor rule parameters nor the volatility of shocks change over time, the variation in the transmission of monetary policy is entirely due to the processes of structural transformation and services deepening.

\subsection{Testable Implication}

We have shown that services deepening provides a mechanism through which the process of sectoral reallocation alters the behavior of sectoral inflation rates. This result defines a novel link between the sectoral composition of intermediate inputs and the response of sectoral inflation rates to shocks. In this Section, we test this novel implication using cross-country panel data. In particular, we test whether manufacturing inflation responds less to (exogenous) changes to the manufacturing value added in countries where manufacturing is more intensive in service inputs.

We combine the World Input-Output database with the WorldKLEMS Initiative to build a panel dataset of 29 countries from 1995 to 2006 on manufacturing price and value added. We are interested in estimating the panel regression

$$
\Delta P_{i, t}^{m}=\alpha+\beta \Delta Y_{i, t}^{m}+\gamma \Delta Y_{i, t}^{m} \times S_{i, 1995}^{m}+\delta X_{i, t}+\chi_{i}+\epsilon_{i, t}
$$


where $\Delta P_{t}^{m}$ defines the inflation rate of manufacturing, $\Delta Y_{t}^{m}$ denotes the change in manufacturing value added, $S_{i, 1995}^{m}$ is the share of service inputs in manufacturing measured in $1995, X_{i, t}$ captures other variables that could explain the change in the manufacturing inflation rate and $\chi_{i}$ is a country fixed effect. The parameter $\gamma$ is associated to our regressor of interest, which is the interaction between changes in the manufacturing value added and the share of service inputs in 1995.

To avoid endogeneity concerns and identify the causal effect of changes in manufacturing value added on manufacturing inflation, we instrument the changes in manufacturing value added with the China shock of Autor et al. (2013). The main idea is that the bulk of the surge of China's export can be viewed as an internal Chinese shock which does not depend on demand conditions of foreign countries. As discussed in Autor et al. (2013) and in the references therein, over the last two decades China has witnessed a dramatic transformation which has also involved the rural-to-urban migration of hundred million workers and the admission to the World Trade Organization in 2001, that permitted the adoption of foreign inputs, capital and technologies.

We build a factor of China's export by averaging the Chinese export flows to all world economies excluding those of our panel. In this way, we can identify the supplydriven part of the rise in Chinese exports. Then, we combine the time-series factor of Chinese exports with countries' share of manufacturing value added in 1995. This share determines the initial exposure of each individual country to the surge in China's exporting capacity. ${ }^{16}$ This procedure yields an index of penetration of Chinese manufactured goods whose cross-sectional heterogeneity can be exploited to instrument the changes in manufacturing value added.

\footnotetext{
${ }^{16}$ China exports mainly manufactured goods. For instance, in 1995 Chinese goods accounted for around $3.8 \%$ of the world manufacturing exports. In 2005 this share has climbed up to $10 \%$.
} 
In addition, we consider a number of controls that could affect the response of inflation to shocks: the log of the real GDP per capita, and measures of trade openness, financial development, and human capital. We also control for the distance in km between China and each country and the effective exchange rate of each country's currency in terms of Chinese renminbi. All these variables are computed in 1995, so they are pre-determined with respect to the shock we are trying to identify.

We run five different regressions. In the first one, we run an OLS with all the control variables and year fixed effects. In the second one, we run the same equation and weight each observation by countries' GDP. In the third one, we run an OLS with country fixed effects. In the fourth one, we run an IV regression with all the controls and year fixed effects. Finally, the fifth one is an IV regression with country fixed effects. Table 5 reports the results.

In all regressions, an increase in the manufacturing value added leads to a reduction in manufacturing inflation. The effect is always statistically different from zero. As predicted by our theory, the effect of changes in manufacturing value added on inflation is decreasing on the share of service inputs. In countries whose manufacturing sector display a high share of service inputs, an increase in manufacturing value added leads to a milder reduction in manufacturing inflation. This dampening effect is statistically and economically significant in all regressions.For instance, in a country like Slovenia that has a $46 \%$ share of service inputs, a $1 \%$ increase in manufacturing value added leads to a reduction in the inflation rate that ranges from $-0.12 \%$ to $-0.37 \%$. Instead, if we consider a country which is less intensive in service inputs, such as Korea with its $22 \%$ share of service inputs over total intermediates, changes in manufacturing value added have much larger effects on the manufacturing inflation rate: a $1 \%$ increase in manufacturing value added leads to a reduction in inflation that ranges from to $-0.33 \%$ 
Table 5: Panel Regressions: China Shock and the Change in the Price of Manufactured Goods

Dependent Variable: Change in the Price of Manufactured Goods

$\begin{array}{clll}\text { Weighted } & \text { OLS } & \text { IV } & \text { IV } \\ \text { OLS } & & \end{array}$
(1)
(2)
(3)
(4)
(5)

\begin{tabular}{|c|c|c|c|c|c|}
\hline$\Delta$ Value Added Manuf. & $\begin{array}{l}-0.6616^{\star \star \star} \\
(0.2386)\end{array}$ & $\begin{array}{l}-0.6858^{\star \star \star} \\
(0.2388)\end{array}$ & $\begin{array}{r}-0.5191^{\star \star} \\
(0.2590)\end{array}$ & $\begin{array}{l}-2.2919^{\star} \\
(1.3351)\end{array}$ & $\begin{array}{r}-4.5637^{\star \star} \\
(2.1221)\end{array}$ \\
\hline $\begin{array}{l}\Delta \text { Value Added Manuf. } \times \\
\text { Share Service Inputs in Manuf. }\end{array}$ & $\begin{array}{l}0.0103^{\star \star} \\
(0.0048)\end{array}$ & $\begin{array}{l}0.0108^{\star \star} \\
(0.0047)\end{array}$ & $\begin{array}{l}0.0088^{\star} \\
(0.0050)\end{array}$ & $\begin{array}{l}0.0433^{\star} \\
(0.0261)\end{array}$ & $\begin{array}{l}0.0920^{\star \star} \\
(0.0457)\end{array}$ \\
\hline $\begin{array}{l}\text { Manuf. Value } \\
\text { Added Share }\end{array}$ & $\begin{array}{c}-0.1976^{\star \star} \\
(0.0851)\end{array}$ & $\begin{array}{c}-0.1961^{\star \star} \\
(0.0840)\end{array}$ & & $\begin{array}{l}-0.2295 \\
(0.2515)\end{array}$ & \\
\hline $\begin{array}{l}\text { Share of Service } \\
\text { Inputs in Manuf. }\end{array}$ & $\begin{array}{l}0.0668^{\star} \\
(0.0366)\end{array}$ & $\begin{array}{l}0.0679^{\star} \\
(0.0374)\end{array}$ & & $\begin{array}{l}-0.0102 \\
(0.1100)\end{array}$ & \\
\hline $\begin{array}{l}\text { Share of Service } \\
\text { Inputs in Services }\end{array}$ & $\begin{array}{c}-0.1392^{\star \star} \\
(0.0699)\end{array}$ & $\begin{array}{c}-0.1384^{\star \star} \\
(0.0682)\end{array}$ & & $\begin{array}{c}-0.1979^{\star} \\
(0.1172)\end{array}$ & \\
\hline GDP per Capita & $\begin{array}{l}-0.0372^{\star \star \star} \\
(0.0114)\end{array}$ & $\begin{array}{c}-0.0389^{\star \star \star} \\
(0.0116)\end{array}$ & & $\begin{array}{c}-0.0361^{\star \star} \\
(0.0174)\end{array}$ & \\
\hline Financial Development & $\begin{array}{l}-0.0160 \\
(0.0102)\end{array}$ & $\begin{array}{l}-0.0148 \\
(0.0099)\end{array}$ & & $\begin{array}{r}-0.0257^{\star \star} \\
(0.0130)\end{array}$ & \\
\hline Trade Openness & $\begin{array}{l}-0.0027 \\
(0.0101)\end{array}$ & $\begin{array}{l}-0.0041 \\
(0.0101)\end{array}$ & & $\begin{array}{l}-0.0059 \\
(0.01465)\end{array}$ & \\
\hline Human Capital & $\begin{array}{c}0.0935 \\
(0.0682)\end{array}$ & $\begin{array}{c}0.0954 \\
(0.0686)\end{array}$ & & $\begin{array}{c}0.0846 \\
(0.0652)\end{array}$ & \\
\hline Distance & $\begin{array}{c}0.0040 \\
(0.0066)\end{array}$ & $\begin{array}{c}0.0040 \\
(0.0064)\end{array}$ & & $\begin{array}{l}-0.0087 \\
(0.0126)\end{array}$ & \\
\hline Exchange Rate & $\begin{array}{l}0.0036^{\star \star} \\
(0.0014)\end{array}$ & $\begin{array}{l}0.0034^{\star \star} \\
(0.0014)\end{array}$ & & $\begin{array}{c}0.0035 \\
(0.0027)\end{array}$ & \\
\hline Country FE & $\mathrm{NO}$ & $\mathrm{NO}$ & YES & NO & YES \\
\hline Year FE & YES & NO & $\mathrm{NO}$ & YES & NO \\
\hline N. Obs. & 319 & 319 & 319 & 319 & 319 \\
\hline
\end{tabular}

Note: The panel covers 29 countries from 1996 to 2006 . The dependent variable in all regressions is the log difference of the price of manufactured goods (i.e., the price deflator of the manufacturing value added). $\Delta$ Value Added Manuf. defines the log difference of the real value added in manufacturing. Share Service Inputs in Manuf. denotes the share of service inputs to total intermediates in manufacturing. Share Service Inputs in Services denotes the share of service inputs to total intermediates in services. Manuf. Value Added Share defines the share of manufacturing value added to total value added. For the definition of Financial Development, Trade Openness and Human Capital see Table ??. Distance defines the log distance in $\mathrm{km}$ between each country and China. Exchange Rate denotes the log exchange rate of the currency of each country vs. Chinese renminbi. Weighted regressions are run by weighting each observation by countries' log real GDP in 1995 . Robust standard errors are reported in brackets. $\star, \star \star$, and $\star \star \star$ indicate statistical significance at the $10 \%, 5 \%$ and $1 \%$, respectively. 
to $-2.58 \%$. These results confirm that the sectoral composition of intermediate inputs characterizes the response of sectoral inflation rates to shocks. ${ }^{17}$

\section{Conclusion}

In this paper we study how the transmission of monetary policy changes with the sectoral composition of an economy. In particular, we look at the implications of the process of sectoral reallocation that advanced economies experience over time.

We document that the structural transformation from manufacturing to services comes with a process of services deepening: over time both services and manufacturing become more intensive in service inputs.

We build a New Keynesian model with two sectors connected by an Input-Output matrix, which changes endogenously over time, to understand the effects of the sectoral reallocation experienced by the U.S. from 1947 to 2005. We find that over these six decades the reaction of aggregate inflation to monetary policy shocks decreases by $37 \%$, whereas the response of aggregate output rises by $10 \%$.

We show that services deepening reduces the responsiveness of inflation through a marginal cost channel that affects the behavior of firms in either sector. As services and manufacturing increase the intensity of service inputs, marginal costs becomes stickier. Thus, even sectoral prices become stickier and less reactive to monetary policy shocks.

Finally, to further validate the mechanism of our model, we test the novel implication on the link between the sectoral composition of inputs and the dynamics of sectoral prices. To do so, we use cross-country panel data and instrument the changes in manufacturing GDP with the China shock of Autor et al. (2013). Consistently with our theory, we find that manufacturing inflation responds less to (exogenous) changes in manufacturing GDP in countries where manufacturing is more intensive in service inputs.

\footnotetext{
${ }^{17}$ As emphasized in Section 2.2, a higher share of service intermediate inputs can dampen the response of manufacturing inflation to shocks through different mechanisms (e.g., wage stickiness is more important in services inputs because they are characterized by a high labor share; services inputs face a lower degree of market competition than manufacturing inputs; there is a larger turnover in durable manufacturing goods rather than in services).
} 


\section{References}

Acemoglu, D., U. Akcigit, and W. Kerr (2015) "Networks and the Macroeconomy: An Empirical Exploration". NBER Macroeconomics Annual, 30, 276-335.

Acemoglu, D., and V. Guerrieri (2008) "Capital Deepening and Nonbalanced Economic Growth". Journal of Political Economy, 116, 467-98.

Autor, D., D. Dorn, and G. Hanson (2013) "The China Syndrome: Local Labor Market Effects of Import Competition in the United States". American Economic Review, 103, 2121-68.

Barsky, R., C. House and M. Kimball (2007) "Stocky-Price Models and Durable Goods". American Economic Review, 97, 984-98.

Basu, S. (1995) "Intermediate Goods and Business Cycles: Implications for Productivity and Welfare". American Economic Review, 85, 512-31.

Baumol, W. (1967) "Macroeconomics of Unbalanced Growth: The Anatomy of Urban Crisis". American Economic Review, 57, 415-26.

Berlingieri, G. (2014) "Outsourcing and the Rise in Services". Mimeo.

Bils, M., and P. Klenow (2004) "Some Evidence on the Importance of Sticky Prices". Journal of Political Economy, 112, 947-85.

Boivin, J., and M. Giannoni (2006) "Has Monetary Policy Become More Effective?" Review of Economics and Statistics, 88, 445-62.

Bouakez, H., E. Cardia, and F. Ruge-Murcia (2009) "The Transmission of Monetary Policy in a Multi-Sector Economy". International Economic Review, 50, 1243-66.

Bouakez, H., E. Cardia, and F. Ruge-Murcia (2011) "Durable Goods, InterSectoral Linkages and Monetary Policy". Journal of Economic Dynamics and Control, $35,730-45$.

Buera, F., and J. Kaboski (2012) "The Rise of the Service Economy". American Economic Review, 102, 2540-69. 
Buera, F., J. Kaboski, and Y. Shin (2011) "Finance and Development: A Tale of Two Sectors". American Economic Review, 101, 1964-2002.

Calvo, G. (1983) "Staggered Prices in a Utility-Maximizing Framework". Journal of Monetary Economics, 12, 383-98.

Carvalho, C. (2006) "Heterogeneity in Price Stickiness and the Real Effects of Monetary Shocks". B.E. Journal of Macroeconomics, 2, 1-56.

Carvalho, V., and X. Gabaix (2013) "The Great Diversification and Its Undoing". American Economic Review, 103, 1697-727.

Clarida, R., J. Gali, and M. Gertler (2000) "Monetary Policy Rules And Macroeconomic Stability: Evidence And Theory". Quarterly Journal of Economics, 115, 147-80. Christiano, L., M. Eichenbaum, and C. Evans (2005) "Nominal Rigidities and the Dynamic Effects of a Shock to Monetary Policy". Journal of Political Economy, 113, $1-45$.

Cogley, T., and T. Sargent (2001) "Evolving Post-World War II U.S. Inflation Dynamics". NBER Macroeconomics Annual, 16, 331-88.

Cogley, T., and T. Sargent (2005) "Drifts and Volatilities: Monetary Policies and Outcomes in the Post-WWII US". Review of Economic Dynamics, 8, 262-302.

Duarte, M., and D. Restuccia (2010) "The Role of Structural Transformation in Aggregate Productivity". Quarterly Journal of Economics, 125, 129-73.

Erceg, C., and A. Levin (2006) "Optimal Monetary Policy with Durable Consumption Goods". Journal of Monetary Economics, 53, 134-59.

Fernandez-Villaverde, J., and J. Rubio-Ramirez (2007) "How Structural are Structural Parameter Values?" NBER Macroeconomics annual, 22, 83-137.

Foerster, A., P.-D. Sarte, and M. Watson (2011) "Sectoral versus Aggregate Shocks: A Structural Factor Analysis of Industrial Production". Journal of Political Economy, 119, 1-38.

Herrendorf, B., R. Rogerson and A. Valentinyi (2013) "Two Perspectives on Preferences and Structural Transformation". American Economic Review, 103, 2752-89. 
Huang, K., and Z. Liu (2005) "Inflation Targeting: What Inflation Rate to Target?". Journal of Monetary Economics, 52, 1435-62.

Hulten, C. (1978) "Growth Accounting with Intermediate Goods". Review of Economic Studies, 45, 511-18.

Jorgenson, D. (2007) "35 Sector KLEM". Harvard Dataverse.

Klenow, P., and O. Kryvtsov (2008) "State-Dependent and Time-Dependent Pricing: Does It Matter for U.S. Inflation?" Quarterly Journal of Economics, 123, 863-904. Kongsamut, P., S. Rebelo, and D. Xie (2001) "Beyond Balanced Growth". Review of Economic Studies, 68, 869-82.

Long, J., and C. Plosser (1983) "Real Business Cycles". Journal of Political Economy, 91, 39-69.

Moro, A. (2012) "The Structural Transformation Between Manufacturing and Services and the Decline in the US GDP Volatility". Review of Economic Dynamics, 15, 402-15. Moro, A. (2015) "Structural Change, Growth, and Volatility". American Economic Journal: Macroeconomics, 7, 259-94.

Nakamura, E., and J. Steinsson (2008) "Five Facts about Prices: A Reevaluation of Menu Cost Models". Quarterly Journal of Economics, 123, 1415-64.

Nakamura, E., and J. Steinsson (2010) "Monetary Non-Neutrality in a Multisector Menu Cost Model". Quarterly Journal of Economics, 125, 961-1013.

Ngai, R., and C. Pissarides. (2007) "Structural Change in a Multisector Model of Growth". American Economic Review, 97, 429-43.

Pancrazi, R., and M. Vukotic (2016) "Has Monetary Policy Maintained its Effectiveness?" Mimeo.

Primiceri, G. (2005) "Time Varying Structural Vector Autoregressions and Monetary policy". Review of Economic Studies, 72, 821-52.

Smets, F., and R. Wouters (2007) "Shocks and Frictions in US Business Cycles: A Bayesian DSGE Approach". American Economic Review, 97, 586-606. 


\title{
BANCO DE ESPAÑA PUBLICATIONS
}

\author{
WORKING PAPERS
}

1501 LAURA HOSPIDO and EVA MORENO-GALBIS: The Spanish productivity puzzle in the Great Recession.

1502 LAURA HOSPIDO, ERNESTO VILLANUEVA and GEMA ZAMARRO: Finance for all: the impact of financial literacy training in compulsory secondary education in Spain.

1503 MARIO IZQUIERDO, JUAN F. JIMENO and AITOR LACUESTA: Spain: from immigration to emigration?

1504 PAULINO FONT, MARIO IZQUIERDO and SERGIO PUENTE: Real wage responsiveness to unemployment in Spain: asymmetries along the business cycle.

1505 JUAN S. MORA-SANGUINETTI and NUNO GAROUPA: Litigation in Spain 2001-2010: Exploring the market for legal services.

1506 ANDRES ALMAZAN, ALFREDO MARTÍN-OLIVER and JESÚS SAURINA: Securitization and banks' capital structure.

1507 JUAN F. JIMENO, MARTA MARTÍNEZ-MATUTE and JUAN S. MORA-SANGUINETTI: Employment protection legislation and labor court activity in Spain.

1508 JOAN PAREDES, JAVIER J. PÉREZ and GABRIEL PEREZ-QUIRÓS: Fiscal targets. A guide to forecasters?

1509 MAXIMO CAMACHO and JAIME MARTINEZ-MARTIN: Monitoring the world business cycle.

1510 JAVIER MENCÍA and ENRIQUE SENTANA: Volatility-related exchange traded assets: an econometric investigation.

1511 PATRICIA GÓMEZ-GONZÁLEZ: Financial innovation in sovereign borrowing and public provision of liquidity.

1512 MIGUEL GARCÍA-POSADA and MARCOS MARCHETTI: The bank lending channel of unconventional monetary policy: the impact of the VLTROs on credit supply in Spain.

1513 JUAN DE LUCIO, RAÚL MÍNGUEZ, ASIER MINONDO and FRANCISCO REQUENA: Networks and the dynamics of firms' export portfolio.

1514 ALFREDO IBÁÑEZ: Default near-the-default-point: the value of and the distance to default.

1515 IVÁN KATARYNIUK and JAVIER VALLÉS: Fiscal consolidation after the Great Recession: the role of composition.

1516 PABLO HERNÁNDEZ DE COS and ENRIQUE MORAL-BENITO: On the predictability of narrative fiscal adjustments.

1517 GALO NUÑO and CARLOS THOMAS: Monetary policy and sovereign debt vulnerability.

1518 CRISTIANA BELU MANESCU and GALO NUÑO: Quantitative effects of the shale oil revolution.

1519 YAEL V. HOCHBERG, CARLOS J. SERRANO and ROSEMARIE H. ZIEDONIS: Patent collateral, investor commitment and the market for venture lending.

1520 TRINO-MANUEL ÑIGUEZ, IVAN PAYA, DAVID PEEL and JAVIER PEROTE: Higher-order risk preferences, constant relative risk aversion and the optimal portfolio allocation.

1521 LILIANA ROJAS-SUÁREZ and JOSÉ MARÍA SERENA: Changes in funding patterns by Latin American banking systems: how large? how risky?

1522 JUAN F. JIMENO: Long-lasting consequences of the European crisis.

1523 MAXIMO CAMACHO, DANILO LEIVA-LEON and GABRIEL PEREZ-QUIROS: Country shocks, monetary policy expectations and ECB decisions. A dynamic non-linear approach.

1524 JOSÉ MARÍA SERENA GARRALDA and GARIMA VASISHTHA: What drives bank-intermediated trade finance? Evidence from cross-country analysis.

1525 GABRIELE FIORENTINI, ALESSANDRO GALESI and ENRIQUE SENTANA: Fast ML estimation of dynamic bifactor models: an application to European inflation.

1526 YUNUS AKSOY and HENRIQUE S. BASSO: Securitization and asset prices.

1527 MARÍA DOLORES GADEA, ANA GÓMEZ-LOSCOS and GABRIEL PEREZ-QUIROS: The Great Moderation in historical perspective. Is it that great?

1528 YUNUS AKSOY, HENRIQUE S. BASSO, RON P. SMITH and TOBIAS GRASL: Demographic structure and macroeconomic trends.

1529 JOSÉ MARÍA CASADO, CRISTINA FERNÁNDEZ and JUAN F. JIMENO: Worker flows in the European Union during the Great Recession.

1530 CRISTINA FERNÁNDEZ and PILAR GARCÍA PEREA: The impact of the euro on euro area GDP per capita.

1531 IRMA ALONSO ÁLVAREZ: Institutional drivers of capital flows.

1532 PAUL EHLING, MICHAEL GALLMEYER, CHRISTIAN HEYERDAHL-LARSEN and PHILIPP ILLEDITSCH: Disagreement about inflation and the yield curve.

1533 GALO NUÑO and BENJAMIN MOLL: Controlling a distribution of heterogeneous agents. 
1534 TITO BOERI and JUAN F. JIMENO: The unbearable divergence of unemployment in Europe.

1535 OLYMPIA BOVER: Measuring expectations from household surveys: new results on subjective probabilities of future house prices.

1536 CRISTINA FERNÁNDEZ, AITOR LACUESTA, JOSÉ MANUEL MONTERO and ALBERTO URTASUN: Heterogeneity of markups at the firm level and changes during the great recession: the case of Spain.

1537 MIGUEL SARMIENTO and JORGE E. GALÁN: The influence of risk-taking on bank efficiency: evidence from Colombia.

1538 ISABEL ARGIMÓN, MICHEL DIETSCH and ÁNGEL ESTRADA: Prudential filters, portfolio composition and capital ratios in European banks.

1539 MARIA M. CAMPOS, DOMENICO DEPALO, EVANGELIA PAPAPETROU, JAVIER J. PÉREZ and ROBERTO RAMOS: Understanding the public sector pay gap.

1540 ÓSCAR ARCE, SAMUEL HURTADO and CARLOS THOMAS: Policy spillovers and synergies in a monetary union.

1601 CHRISTIAN CASTRO, ÁNGEL ESTRADA and JORGE MARTÍNEZ: The countercyclical capital buffer in Spain: an analysis of key guiding indicators.

1602 TRINO-MANUEL ÑÍGUEZ and JAVIER PEROTE: Multivariate moments expansion density: application of the dynamic equicorrelation model.

1603 ALBERTO FUERTES and JOSÉ MARÍA SERENA: How firms borrow in international bond markets: securities regulation and market segmentation.

1604 ENRIQUE ALBEROLA, IVÁN KATARYNIUK, ÁNGEL MELGUIZO and RENÉ OROZCO: Fiscal policy and the cycle in Latin America: the role of financing conditions and fiscal rules.

1605 ANA LAMO, ENRIQUE MORAL-BENITO and JAVIER J. PÉREZ: Does slack influence public and private labour market interactions?

1606 FRUCTUOSO BORRALLO, IGNACIO HERNANDO and JAVIER VALLÉS: The effects of US unconventional monetary policies in Latin America.

1607 VINCENZO MERELLA and DANIEL SANTABÁRBARA: Do the rich (really) consume higher-quality goods? Evidence from international trade data.

1608 CARMEN BROTO and MATÍAS LAMAS: Measuring market liquidity in US fixed income markets: a new synthetic indicator.

1609 MANUEL GARCÍA-SANTANA, ENRIQUE MORAL-BENITO, JOSEP PIJOAN-MAS and ROBERTO RAMOS: Growing like Spain: 1995-2007

1610 MIGUEL GARCÍA-POSADA and RAQUEL VEGAS: Las reformas de la Ley Concursal durante la Gran Recesión.

1611 LUNA AZAHARA ROMO GONZÁLEZ: The drivers of European banks' US dollar debt issuance: opportunistic funding in times of crisis?

1612 CELESTINO GIRÓN, MARTA MORANO, ENRIQUE M. QUILIS, DANIEL SANTABÁRBARA and CARLOS TORREGROSA: Modelling interest payments for macroeconomic assessment.

1613 ENRIQUE MORAL-BENITO: Growing by learning: firm-level evidence on the size-productivity nexus.

1614 JAIME MARTÍNEZ-MARTÍN: Breaking down world trade elasticities: a panel ECM approach.

1615 ALESSANDRO GALESI and OMAR RACHEDI: Structural transformation, services deepening, and the transmission of monetary policy.

BANCODEESPAÑA Eurosistema
Unidad de Servicios Auxiliares

Alcalá, 48 - 28014 Madrid

E-mail: publicaciones@bde.es www.bde.es 